\title{
An Evaluation of Liners for a Uranium-Mill Tailings Disposal Site-A Status Report
}

\author{
J. L. Buelt \\ V. Q. Hale \\ S. M. Barnes \\ D. J. Silviera
}

May 1981

Prepared for the U.S. Department of Energy under Contract DE-AC06-76RLO 1830

Pacific Northwest Laboratory Operated for the U.S. Department of Energy by Battelle Memorial Institute

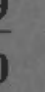




\title{
NOTICE
}

This report was prepared as an account of work sponsored by the United States Government. Neither the United States nor the Department of Energy, nor any of their employees, nor any of their contractors, subcontractors, or their employees, makes any warranty, express or implied, or assumes any legal liability or responsibility for the accuracy. completeness or usefulness of any information, apparatus, product or process disclosed, or represents that its use would not infringe privately owned rights.

The views; opinions and conclusions contained in this report are those of the contractor and do not necessarily represent those of the United States Government or the United States Department of Energy.

\author{
PACIFIC NORTHWEST LABORATORY \\ operated by \\ BATTELLE \\ for the \\ UNITED STATES DEPARTMENT OF ENERGY \\ Under Contract DE-AC06-76RLO 1830
}

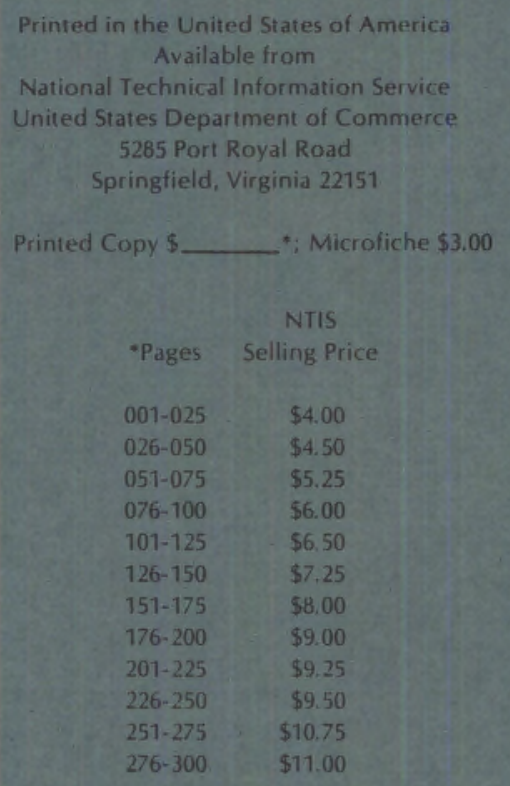



J. L. Buelt
V. Q. Hale
S. M. Barnes
D. J. Silviera

May 1981

Prepared for

the U.S. Department of Energy

under Contract DE-ACO6-76RL0 1830

Pacific Northwest Laboratory

Richland, Washington 99352 
- 


\section{SUMMARY}

The United States Department of Energy is conducting a program designed to reclaim or stabilize inactive uranium-mill tailings sites. As part of this program, known as the Uranium Mill Tailings Remedial Action (UMTRA) Program, the Pacific Northwest Laboratory is evaluating existing liner materials for their effectiveness in preventing migration of water-soluble radionuclides and hazardous chemicals over the long term. This report presents the status of the Pacific Northwest Laboratory's evaluation.

Proposed regulatory requirements were reviewed to determine material performance criteria; then, potential liner materials were screened for their effectiveness under expected exposure conditions identified in a tailings characterization study. The liner criteria are that the liner must be effective for $1000 \mathrm{yr}$, have less than $10^{-7} \mathrm{~cm} / \mathrm{s}$ permeability, and must be unaffected by leachate contact and weathering conditions. The materials were screened through literature evaluations and industrial contacts. The materials studied included locally available clays and soils, soil treatments, bentonite amendments to soil, asphalt membranes, asphalt concretes, treated grouts and concretes, and elastomeric and plastic membranes. Of these categories, eight liners were chosen for laboratory testing under accelerated exposure conditions. The characterization study, carried out to help define those conditions, identified the wide variability in pH, calcium concentration, anions, and radionuclide content.

The status report also presents the information gathered during the field studies at Grand Junction, Colorado. Two liners, a bentonite, sand, and grave mixture, and a catalytic airblown asphait membrane, were installed in a prepared trench and covered with tailings. The liners were instrumented and are being monitored for migration of moisture, radionuclides, and hazardous chemicals. The two liner materials will also be subjected to accelerated laboratory tests for a comparative assessment.

The eight materials selected for laboratory testing are:

- natural soil amended with sodium-saturated montmorillonite (Volclay); 
- locally available clay in conjunction with an asphalt emulsion radon suppression cover;

- locally available clay in conjunction with a multibarrier radon suppression cover;

- rubberized asphalt membrane;

- hydraulic asphalt concrete;

- chlorosulfonated polyethylene (hypalon) or high-density polyethylene;

- bentonite, sand and gravel mixture;

- catalytic airblown asphalt membrane.

The materials will be exposed in test units now being constructed to conditions such as wet/dry cycles, temperature cycles, oxidative environments, ionexchange elements, etc. The results of the tests will identify the best material for field study. 


\section{CONTENTS}

SUMMARY

FIGURES

TABLES

INTRODUCTION

CURRENT REGULATORY REQUIREMENTS FOR URANIUM MILL TAILINGS DISPOSAL

$i j i$

vij

vij

EPA STANDARDS

5

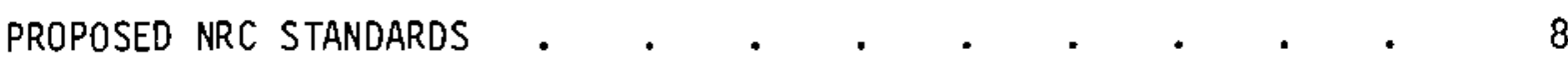

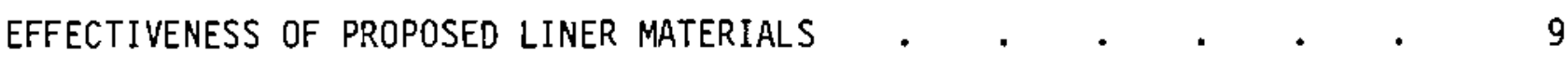

CLAYS

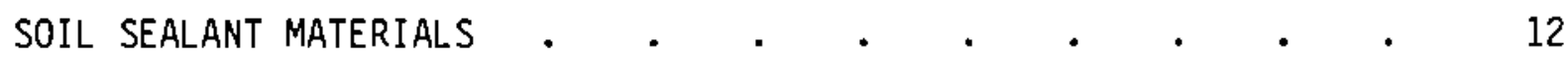

ASPHALTS • . $\quad . \quad$. . . . . . . . . . . . 13

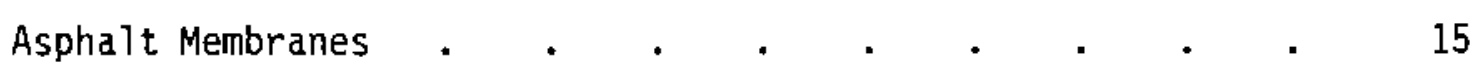

Asphalt Concretes . . . . . . . . . . . . . . 16

CONCRETES . $\quad . \quad$. $\quad . \quad$.

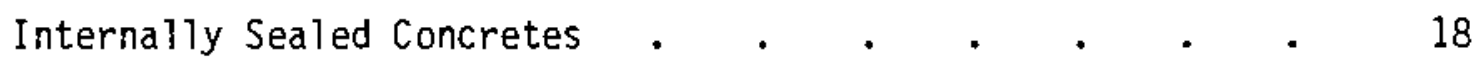

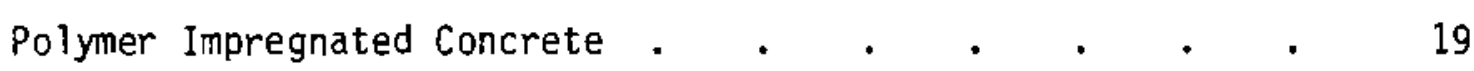

Polymer-Portland Cement Concrete . . . . . . . 20

Polymer Concrete $\quad . \quad$. $\quad . \quad$. . . . . . . . 21

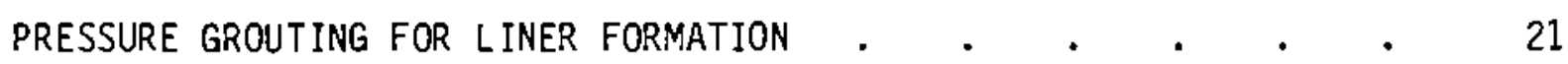

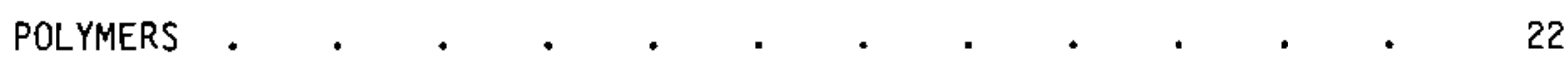

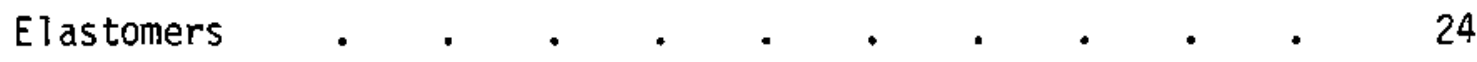

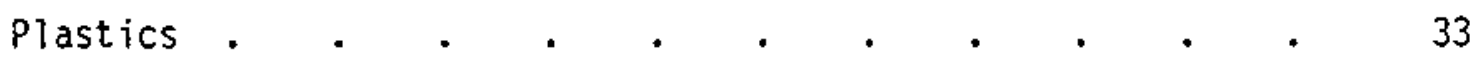

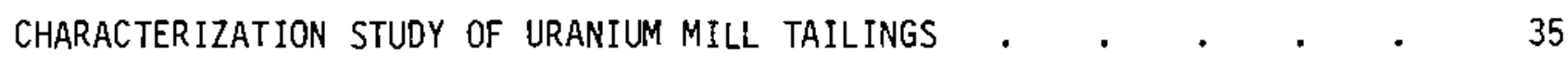

FIELD STUDIES 


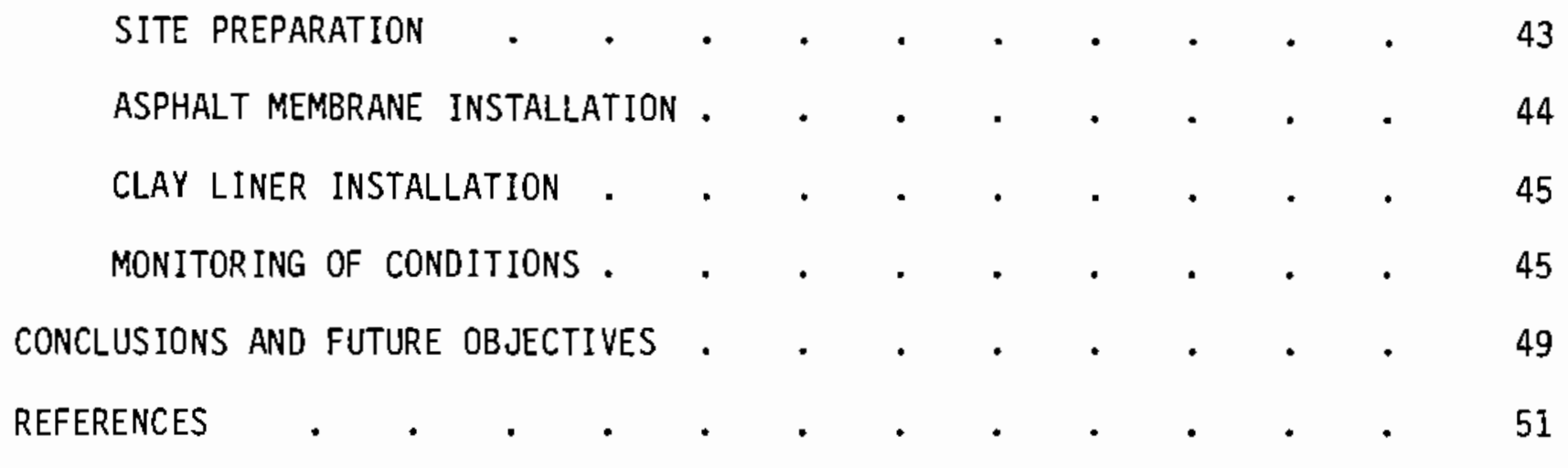




\section{FIGURES}

1 Milestones of Inactive Uranium Mill Tailings Program . . $\quad$. 7

2 Sample Sites on the Salt Lake City Vitro Tailings Pile . . . 35

3 Sample Sites on the Durango Tailings Pile . . . . . 36

4 Sample Sites on the Shiprock Tailings Pile . . . . . 37

5 Trench Dimensions for Liner Field Test . . . . . . . 43

6 Application of Asphalt Membrane . . . . . . . . 46

7 Trench After Clay and Asphalt Liners Installed . • . . 47

8 Moisture Extraction Cups and Moisture Blocks . . . . . 48

\section{$\underline{\text { TABLES }}$}

1 Characterization of Morton Ranch Clay Liner and Sandstone . . 11

2 EPA Criteria and Morton Ranch Clay Liner Characteristics . . 12

3 Representative Soil Sealants . . . . . . . . . 14

4 Internally Sealed Concrete Specification . . . . . . 19

5 Sumary of the Effects of Immersion of Polymeric Membrane Liners in Leachate for Eight Months . . . . . . . 24

6 Effect of Immersing Liner and Sealing Materials in Hazardous

7 Properties of Polymeric Liner Membranes Installed as Barriers . . . . . . . . . . . . 28

8 Effect of Gamma Radiation on Physical Properties . . . . 31

9 Effect on Properties of Polymeric Membrane Liners of One Year of Exposure to Leachate from Simulated Sanitary Landfills . . 32

10 Analytical Results from Tailings at Salt Lake, Durango and Shiprock Sites Using 100:1 Leachant-to-Sample Ratio . . . . 39

11 Moisture Profiles at Great Salt Lake Desert Sites . . . . . 41

12 Asphalt Membrane Specifications . . . . . . . . 44 



\section{INTROOUCTION}

Within the United States, inactive uranium-mill tajlings that resulted from the production of uranium for the nation's nuclear-weapons arsenal are present at a number of sites. In 1974, the Subcommittee on Raw Materials of the Joint Conmittee on Atomic Energy of the United States Congress held hearings to consider bills calling for action to be taken at the vitro site in Salt Lake City, Utah, to reduce or eliminate the danger to individuals from exposure to radiation from the tailings. During the hearings, a number of other sites with similar problems was identified. Accordingly, a public law was passed for the reclamation of 25 inactive sites, and an initial assessment of sites began that same year.

of the sites for which remedial action is planned, 24 are located in the Western states. A tailings site produced from various uranium processing activities also exists in one Eastern state. The principal radionuclides in the western states are of the uranium-238 decay chain, primarily thorium-230,

radium-226 and radon-222, and its progeny. of these, ${ }^{226} R a$ is of greatest concern as a potential ground-water contaminant. The tailings also include as potential ground-water pollutants some nonradioactive chemicals that were either introduced or liberated from the ore in the milling process.

A1l of the identified sites that fall within the scope of the Uranium Mill Tailings Remedial Action Program (UMTRAP) will require some remedial action, but not all of the sites have equal priority nor are they all likely to require the same treatment. Four sites that have priority consideration are at Salt Lake City; Durango, Colorado; Shiprock, New Mexico; and Canonsburg, Pennsylvania. Since each of these sites is located in or near a population center, it will probably be necessary to remove the tailings and place them in repositories at carefully selected sites. These repositories will, hopefully, confine the tailings and their potential leachates for an extensive geologic time. Tailings from other sites may also require removal, either from or within their present sites, to assure that permanent repositories control leaching within acceptable limits. 
The repository sites to which these tailings will be removed have not been selected, although in some cases a number of potential sites has been identified. Once a site has been selected, its soil characteristics need to be determined so that a judgment $c$ an be made about how the site needs to be prepared. This preparation may only require excavation if the soils are highly impervious, or may require that an excavation be lined with a highly impervious material. The effectiveness of these soils and lining materials needs to be evaluated for use by architectural designers by the end of calendar year 1981.

The most effective liner for a repository may be selected from several materials. These include asphalts, clay and synthetic materials. Though they are considered in this study, synthetic materials are not expected to be viable candidates because they have not had a history of applications over the timescale required. Asphalts and clays have had long-term usage, and either may meet the needs of a particular site. However, these materials need to be evaluated under the conditions to which they will be subjected to determine their durability. The Liner Evaluation Program performed by the Pacific Northwest Laboratory (PNL) is conducting field studies and accelerated laboratory tests to evaluate in a short time period the performance of various liners over the long term. This evaluation considers not only the characteristics of the tailings, but also such $c l$ imatic conditions as repeated freezing-thawing and wetting-drying. With these kinds of information, a judgment can be made as to the preferred liner material to meet the needs of a particular site.

This report presents the status of the Liner Evaluation Program. The purpose of the study was to identify eight prospective lining materials or composites for laboratory testing. The evaluation was performed by 1 ) reviewing proposed regulatory requirements to define the material performance criteria; 2) reviewing published literature and comunicating with industrial and government experts experienced with lining materals and techniques; and 3) characterizing the tailings at three of the sites for cations, a selection of anions, radionuclides, organic solvents, and acidity levels. 
The report also describes PNL's liner experience during field work at an actual site. In this portion of the study, two liners, which passed a brief acceptability review, were installed at the Grand Junction tailings pile for later comparison with laboratory results. These field studies also gave the investigators "hands-on" experience with installation practices. 
: 


\section{CURRENT REGULATORY REQUIREMENTS FOR URANIUM MILL TAILINGS DISPOSAL}

Under the Uranium Mill Tailings Radiation Control Act of 1978 (PL 95-604), the Environmental Protection Agency (EPA) is responsible for developing environmental standards that will assure that management and disposal of uraniummill tailings in the United States is consistent with the overall goal of protection of the health and safety of future generations.

In turn, the Nuclear Regulatory Commission (NRC) is responsible for establishing the regulations that will ensure that the disposal methods are consistent with the environmental standards established by the EPA. Specificaliy, the ARC is responsible for licensing and regulating the sites chosen for disposal of the uranium mill tailings. The NRC and the Department of Energy are responsible for ensuring the safety and safeguards of the tailings during transport.

If existing tailings sites do not meet the EPA standards as determined by the NRC and the Department of Energy (DOE), the DOE will develop remedial action programs for the disposal of each site. The Liner Evaluation Program was created in response to this need. The material performance criteria were first identified to ascertain whether selected liner materials for laboratory testing meet these proposed regulations.

\section{EPA STANDARDS}

Proposed EPA standards governing the disposal of tailings at inactive mi11 sites should soon be published in the Federal Register for public coment (45 Federal Register 27366). There is a reasonable expectation, based on current thinking, that the disposal standards will apply for $1000 \mathrm{yr}$ following disposal of the tailings (45 Federal Register 44159). Therefore, the selected liners must be exposed to conditions in the laboratory representative of $1000 \mathrm{yr}$.

If offsite permanent disposal is selected by the DOE, potential sites will be recommended by the respective states that will then be evaluated by the DOE and the NRC. Once a disposal site has been selected, the DOE will develop a 
plan to handie the waste with concurrence by the affected states and the NRC. After completion, the DOE and NRC will certify that the sites meet EPA standards.

Remedial actions at the inactive tailings sites are planned to begin in 1983, contingent on issuance of the final EPA standards, DOE/state cooperative agreements, NRC concurrence, and funding appropriated by Congress and the States. Figure 1 describes the process and time table in more detail.

The EPA has proposed criteria for liner materials for impoundments containing hazardous waste (Federal Register 43: 58946-59026). These same criteria provide guidelines for evaluating the effectiveness of liners for impoundments holding uranium-mill tailings even though liners not meeting the criteria could be used provided that the materials and methods chosen will provide equivalent or greater structural stability, waste containment, and . attenuation and will not be affected by the anticipated waste. These criteria that might be applied to uranium-mill tailings impoundments include certain textural, particle-size, pH, and permeability specifications, some of which are identified below:

For soil liners:

- liner permeability $\leq 1 \times 10^{-7} \mathrm{~cm} / \mathrm{s}$;

- allow greater than 30\% passage through a Number 200 sieve;

- have a pH of 7 or higher;

- have a liquid limit equal to or greater than 30 units;

- have plasticity equal to or greater than 15 units;

- have a permeability not adversely affected by the anticipated waste. For synthetic-membrane liner materials:

- be of adequate strength and thickness to ensure mechanical integrity and have a minimum thickness of 20 mils;

- be compatible with the waste to be landfilled;

- be resistant to attack from soil bacteria and fungus;

- have ample weather resistance to withstand the stress of extreme heat, freezing, and thawing; 


\begin{tabular}{|c|c|c|c|}
\hline AGENCY & STRATEGY & 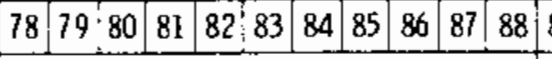 & \begin{tabular}{|l|l|l|l|l|l|l|l|l|l|l|l|l|l|}
9 & 90 & 91 & 92 & 93 & 94 & 95 & 96 & 97 & 98 & 99 & 2000 \\
\end{tabular} \\
\hline \multirow[t]{2}{*}{ CONGRESS } & PASS LEGISLATION & $\nabla$ & \\
\hline & APPROPRIATE FUNDS & $\triangle----ー------$ & ------- \\
\hline \multirow[t]{2}{*}{ EPA } & INACTIVE SITE CLEANUP STANDARDS & $\triangle-\nabla$ & \\
\hline & INACIIVE SITE DISPOSAL STANDAROS & $\triangle-\nabla$ & \\
\hline \multirow[t]{2}{*}{ NRC } & CONDUCT HEARINGS PRIOR TO LICENSING & $\triangle---\nabla$ & \\
\hline & LICENSE DISPOSAL SITES & $\triangle--\nabla$ & 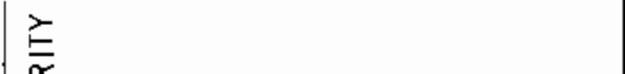 \\
\hline DoJ & DETERMINE LIABILITY & $\triangle---\longrightarrow$ & 옵 \\
\hline \multirow[t]{10}{*}{ DOE } & $\begin{array}{l}\text { DESIGNATE SITES AND DETERMINE } \\
\text { BOUNDARIES }\end{array}$ & $\nabla$ & 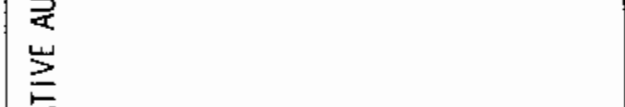 \\
\hline & SET PRIORITIES WITH EPA ADVICE & $\nabla$ & $\underline{s}$ \\
\hline & NEPA COMPLIANCE & $\triangle--\leadsto$ & 墨 \\
\hline & $\begin{array}{l}\text { EXECUTE AGREEMENTS WITH STATES } \\
\text { AND INDIANS }\end{array}$ & $\triangle-\triangle$ & 옳 \\
\hline & EVALUATE MINERAL RECOVERY POTENTIAL & $\triangle F$ & \\
\hline & REMEDIAL ACTION PLAN & $\Delta---\rightarrow \nabla$ & \\
\hline & PUBLIC REVIEW AND HEARINGS & $\triangle---\triangle$ & \\
\hline & PERFORM REMEDIAL ACTION & $\triangle-ー-ー-\leadsto \mid$ & \\
\hline & CERTIFICATION & $\triangle-----$ & $-\nabla$ \\
\hline & MAINTENANCE AND SURVEILLANCE & $\triangle$ & -- \\
\hline
\end{tabular}

$\begin{array}{lll}\triangle \text { START TASK } & \text { DOJ - DEPARTMENT OF JUSTICE } \\ \nabla \text { FINAL } & \text { PROGRAM RELATIONSHIP } & \text { NRC CONCURS ON PRINCIPAL DOE ACTIONS }\end{array}$

FIGURE 1. Milestones of Inactive Uranium Mill Tailings Program (U.S. DOE 1980) 
- have adequate tensile strength to elongate sufficiently and withstand the stress of installation and/or use of machinery and equipment;

- be of uniform thickness, free from thin spots, cracks, tears, blisters, and foreign particles.

\section{PROPOSED NRC STANDARDS}

The NRC has set forth its own set of criteria in its Draft Generic Environmental Impact Statement (NRC 1979). Although the criteria were studied when selecting the prospective liners for laboratory testing, they do not define liner material performance criteria and thus are not discussed here. 


\section{EFFECTIVENESS OF PROPOSED LINER MATERIALS}

Programmatic limitations require that eight of the most prospective liner materials be selected from those available. An evaluation of published literature and industrial contacts narrowed the choice for laboratory testing. The materials considered were clays, soil treatments, asphalt membranes, asphalt concretes, grouts and concretes, and polymeric membranes. The materials were evaluated for the long-term effectiveness as a moisture barrier with cost effectiveness in mind.

\section{$\underline{\text { CLAYS }}$}

Various clay liners have been installed at the bottom of impoundments containing waste materials. These liners include untreated natural clay minerals and clays artifically saturated with sodium to resist loss of sealing properties when leached by wastes of high ionic strength (Fuller 1978; Griffin and Shimp 1978; Haxo 1976a; Haxo and White 1976b; Lubina, Hovater and McCready 1979; Williams 1978; Shultz and Miklas 1980).

The chemical properties of the waste and the methods used for filling the impoundment will influence the choice and design of the liner system. If exposed to natural weathering cycles such as wet/dry and freeze/thaw, a clay liner can lose much of its ability to seal that it had when just installed (Rollins and Dylla 1970). However, if the clay liner is initially hydrated with fresh water and covered to prevent drying, it can form an effective seal.

The sealing property of clays is the result of the ability of the clay to expand when wetted. The expanded clay particles decrease the pore space of the soil and decrease its permeability. Clay minerals called smectites or montmorillonite are generally responsible for this sealing property. Other clay minerals such as illite and kaolinite also expand when wetted, however not as greatly as montmorillonite.

The ions present on the exchange sites of the clays also influence the amount of shrinking and swelling. In the presence of solutions containing high concentrations of dissolved salts, the sodium in the prehydrated clay may 
be replaced by other ions such as calcium and magnesium, causing the clay to shrink and lose some of its effectiveness as a sealant. Sodium-saturated montmorillonite, illite, and kaolinite will swell more than the same clays saturated with calcium. The less swelling clays have been used on a limited basis as sealants. These clays are affected less by increased concentrations of $\mathrm{Mg}$ or $\mathrm{Ca}$, and the shrinkage damage from drying may be less. The decision of which clay minerals to use in the liner will depend on the availability of a particular mineral at specific site locations as well as the characteristics of the leachate within the mill tailings pile.

A special form of montmorillonite called Volclay Saline Seal 100 developed by the American Colloid Company is reported to be resistant to attack by high concentrations of ionic contaminants (Hughes 1974). This material will be studied in the laboratory tests. When specific sites are identified for disposal of the mill tailings, the Saline Seal 100 clay will be mixed with natural soil in the vicinity of the site to determine optimum composition for a clay liner. In addition, clays from typical sites will also be studied to determine sealing properties without the addition of Saline Seal 100. The laboratory studies for natural clay liners will be in conjunction with radon-suppression covers developed by other PNL programs to evaluate their effectiveness for preventing rainwater from entering the tailings.

A big advantage of natural clay minerals over synthetic membrane materials is their low cost (NRC 1979), especially if they can be obtained close to the disposal site. Another advantage of the clay liner is its "self-healing" ability. If the liner fails because of minor breaks, the clay will seal itself by filling up the break in the liner with clay particles over a period of time. This self-healing ability eliminates problems resulting from minor damage to the liner because of ground settling or other causes (Hughes 1974).

As soon as the repository locations are identified for the four priority sites, locally available clays, which have good potential as inexpensive, reliable sealants, will undergo laboratory evaluations. Gee et al. (1980) illustrated the effectiveness of local material clays in their studies of the 
Morton Ranch Uranium Mill Site in central Wyoming. The clay liner material at this site, whose properties are presented in Table 1, was taken from a pit at the Morton Ranch. A comparison of EPA criteria and Morton Ranch clay liner characteristics is presented in Table 2. The data show that the clay meets all EPA criteria.

The data also indicated that for a clay liner $1 \mathrm{~m}$ thick, with a permeability of $10^{-8} \mathrm{~cm} / \mathrm{s}$, the maximum flow through the liner would be less than 2 pore volumes in $20 \mathrm{yr}$ if a constant head of $10 \mathrm{~m}$ was maintained. This maximum flow is equivalent to that through a pond filled with water to a depth of $9 \mathrm{~m}$. This maximum flow value is said to be conservatively high (by a factor of 5 to 10) for most tailings disposal impoundments and certainly would not exist for an impoundment constructed for disposal of tailings from an inactive site. Therefore, the locally available material studied should have sufficient buffer capacity and low permeability to mitigate the tailings leachate for hundreds of years.

TABLE 1. Characterization of Morton Ranch Clay Liner and Sandstone (Gee et al. 1980)

\begin{tabular}{lc}
\multicolumn{1}{c}{ Characterization Parameter } & Value \\
\hline pH of Saturation Paste (Distilled Water) & 8.2 \\
Particle Density, $\mathrm{g} / \mathrm{cm}^{3}$ & 2.72 \\
$\mathrm{CaCO}_{3}$ Equivalent, $\%$ & 0.04 \\
Organic Matter Content, $\%$ & 1.44 \\
Cation Exchange Capacity, meq/100 $\mathrm{g}$ & 31.6 \\
Electrical Conductivity of Saturation & 0.70 \\
Paste, mhos $/ \mathrm{cm}$ & \\
Sodium Adsorption Ratio, meq/L & 0.58 \\
Particle Size 0 istribution: & \\
Sand $(50$ to $2000 \mu \mathrm{m})$ & 12.0 \\
Silt $(2$ to $50 \mu \mathrm{m})$ & 54.0 \\
Clay $(<2 \mu \mathrm{m})$ & 34.0 \\
Surface Area, $\mathrm{m}^{2} / \mathrm{g}$ & 230
\end{tabular}


TABLE 2. EPA Criteria and Morton Ranch Clay Liner Characteristics (Gee et al. 1980)

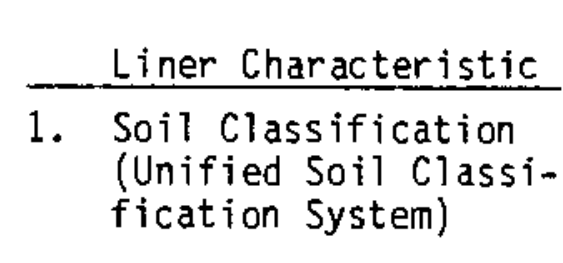

2. Fineness

3. Liquid Limit

4. Plasticity

5. $\mathrm{pH}$

6. Permeability, $\mathrm{cm} / \mathrm{s}$

$\frac{\mathrm{EPA} \text { Criteria }}{\mathrm{CL}, \mathrm{CH}, \mathrm{SC} \text { or } \mathrm{OH}}$

$230 \%$ through 73 $\mu \mathrm{m}$ screen $(200$ mesh

$$
>30
$$

$\geq 15$

$\geq 7$

$10^{-7}$

\author{
Morton Ranch \\ Liner \\ $\mathrm{CL}$ (clayey silt)
}

$95 \%$

43

21

8

$<5 \times 10^{-8}$

The influence of uranium mill tailings leachate on the chemicai properties of the clay liner was also evaluated in Gee et al.'s study. They found that mineralogy of the clay material changes only slightly after extended contact with tailings solution.

There has been some concern over the possible dissolution of soil components by acid leachates. Because an acid leachate will dissolve carbonate minerals in the soil, care must be taken to choose soils that are relatively free of carbonates. The above studies concluded that the mineral dissolution was not a factor in permeability changes for the liner material used at the Morton Ranch Site.

\section{SOIL SEALANT MATERIALS}

Studies have shown that soil permeability can be reduced by the application of various chemicals that react with the soil to form a more impermeable membrane. However, most soil sealants have been reported to be affected by freezing/thawing, wetting/drying, reactions with leachates, and leaching of the sealing agent by the waste liquid (Stewart 1978). 
According to Stewart (1978):

Most of these materials [sealants] consist of a blend of a highmolecular-weight linear polymer and a crosslinked, swellable polymer of approximately the same molecular weight. The linear polymer's many sorptive sites allow it to sorb to the soil and form a flexible network. The cross-linked polymer is extrudable and can conform to permeability channels in the soil without loss of integrity. In use, the polymer system helps to form a stabilized soil surface of extremely low permeability.

Formulation of the polymeric soil sealant system depends on its use, and in most instances, it is considered to be proprietary by the marketing company. When used in unfilled impoundments, the polymer is mixed in a low-pH water/acid solution and then sprayed on the earthen surface as a low-viscosity slurry. The low-pH condition allows the polymer to penetrate the surface. Upon subsequent exposure to water, the water-swellable portion swells and becomes locked in place. The linear polymer, being sorptive in this state, attaches to the soil to complete formation of the stable, impermeable surface.

No actual field data are available, but Stewart (1978) discusses limitations of the sealants, which include shrinkage of the polymer, that thus affects the seal. However, some of the sealants identified by Stewart (1978) in Table 3 will receive additional consideration as the program proceeds.

ASPHALTS

The low water-permeability of asphaltic compositions was known to the ancients. The long-term stability of these compositions is evidenced by the survival of several early asphaltic structures to present times (the Asphait Institute 1976). Asphaits are versatile in their application and their ability to be "alloyed" with various materials, creating compounds to meet a range of situations. Asphalt-based compounds can be formulated for resistance to temperature extremes, water permeability less than $10^{-9} \mathrm{~cm} / \mathrm{s}$ (Hickle 1976), and for a variety of application methods. Asphalts resist most oxidizing acids, except nitric, and attacks from salts and alkalies up to concentrations of $30 \%$ in solution. However, these compounds are:

- oxidized by exposure to ultraviolet radiation; 
IABLE 3. Representative Soil Sealants (Stewart 1978)

Sealant

Cationic Asphalt

Emulsion

Oil-Soluble Polymers

in Diesel Fuel

Sodium Tetraphosphate

Sodium Carbonate

Lignin Derivatives

Gelled Alum

Carboxymethy 1

Cellulose with Alum

Petroleum Emulsions

Attapulgite Clay

Liquid Elastomeric Polymer
Application

Farm Ponds

Fresh Water

Sulfite Liquor Storage

Canais

Desalination Byproduct Brine

Desalination Byproduct Brine

Desalination Byproduct Brine

Desalination Byproduct Brine

Fresh Water
Remarks

Requires $\sim 19,000 \mathrm{~L} / 4,047 \mathrm{~m}^{2} \quad(5,000$ gal/acre) dispersed in water.

Injected beneath surface of water where seepage was occurring.

Dispersant distributed in 15.2- $\mathrm{cm}$ (6-in.) layer of sojl at $2.3 \mathrm{~kg} / 9 \mathrm{~m}^{2}$ ( $5 \mathrm{lb} / 100 \mathrm{ft}^{2}$ ). Careful compaction rendered soil impervious.

Wet-dry cycies disrupt water barrier. Used $183 \mathrm{~g}(0.4 \mathrm{lb})$ of reagent/0.84 $m^{2}\left(y d^{2}\right)$ of soil.

$1 \%$ lignin cost $\$ 3,400 / 4,047 \mathrm{~m}^{2}$ (acre).

$0.2 \%$ CMC cost $\$ 2,250 / 4,047 \mathrm{~m}^{2}$ (acre).

$4 \%$ additive cost $\$ 4,400 / 4,047 \mathrm{~m}^{2}$ $4,047 \mathrm{~m}^{2}$ (acre).

$2 \%$ Zeoge 7 cost $\$ 1,000 / 4,047 \mathrm{~m}^{2}$ (acre).

Patent discloses several compositions, including polyurethane elastometers.

- sometimes attacked by microbes if not protected by biocides;

- susceptible to subgrade displacement due to poor compaction, freeze/ thaw volume changes, and subsidence;

- soluble in solutions $>5 \%$ hydrocarbons.

The subgrade must be treated to prevent penetration of the liner by plant growth below (Stewart 1978; Haxo 1976b; Zobell and Molecke 1978). Should further characterization of the tailings leachate reveal significant quantities of the organics utilized in the solvent extraction process (kerosene, 
isodecanol, and alanine) (NRC 1980), asphaitic liners can be protected by the application of a final tar seal coat.

The asphaltic compositions under consideration for tailings impoundment liners include asphalt membranes, asphalt/fabric membranes, asphaitic concretes, and soil asphalts. These compositions are described below.

\section{Asphalt Membranes}

\section{Rubberized Asphalt Membranes}

Hot-sprayed membranes are prepared by heating a selected asphalt to 220 to $240^{\circ} \mathrm{C}$ and spraying the hot asphalt on a prepared subgrade by a spray bar system. The asphalt selected must meet the temperature requirements for the application, have flexibility at the lowest expected temperature and have sufficient viscosity at the highest expected temperature to resist flowing from sloped sections (The Asphalt Institute 1976). These temperature requirements may be met by adding small quantities ( 2 to $3 \mathrm{wt} \%$ ) of rubber to the asphalt. The rubber decreases the effect of temperature on asphalt viscosity (Dunning 1975). Because of the elastic properties of rubberized asphalt, this material is better suited to anticipated conditions at the tailings repository site, such as subsidence and temperature cycling. Besides liner systems, rubberized asphalts are being developed to prevent crack propagation between layers of airport runways becuase of the materials' pliable nature. They have also been used as a water barrier beneath highway surfaces. The membranes are placed in two layers (lifts) to seal pinholes formed from escaping moisture in the first lift. A typical application rate and thickness of the composition is $7 \mathrm{~L} / \mathrm{m}^{2}$ total and approximately 5 to $8 \mathrm{~mm}$. The membranes must be protected by a layer of soil before heavy equipment is operated above the liner surface (Stewart 1978; Middlebrooks et al. 1978).

\section{Catalytic Airblown Asphalt Membranes}

Catalytic airblown asphalt membranes utilize high-softening-point asphalts to form a membrane seal. Because this style of liner is designed for applications where the liner will be exposed to solar heating, such as canal linings or roofing applications, high-temperature creep properties are very important. 
The asphalt is heated and sprayed in place, as above, but requires a catalyst to modify the viscosity properties of the asphalt for application. Low-temperature ductility is a concern with these asphalts. Haxo and White (1976b) exposed a catalytic asphalt liner to landfill leachate for $1 \mathrm{yr}$ and found that the membrane did not visibly deteriorate and absorbed $2.9 \%$ of the leachate. No firm permeability data were reported, but a significant increase in low shear-rate viscosity was noted. Pre-exposure permeability of catalytic membranes is less than $10^{-9} \mathrm{~cm} / \mathrm{s}$ (Haxo 1976a).

\section{Asphalt Emulsion on Fabric}

These membranes are created by placing fabric mats on the subgrade, sewing the mats to form a single fabric liner, and applying an asphalt emulsion to seal the fabric. The asphait is occasionally chip-sealed to provide additional protection from mechanical damage (The Asphalt Institute 1976; Clark et a]. 1974). Permeabilities of less than $10^{-9} \mathrm{~cm} / \mathrm{s}$ have been reported for this liner style (Haxo and White 1976a).

This form of asphaitic membrane has several iimitations when considered for long-term service. Of primary concern is the small amount of asphait applied. Haxo et a1. (1979), Haxo and White (1976a), and Haxo et al. (1977) report testing an $0.8-\mathrm{cm}$ asphalt emulsion/fabric liner. Should a hole develop in the asphalt and expose the fabric to potentially corrosive materials or the fabric be attacked by elements in the soil, an unsupported $0.8-\mathrm{cm}$ asphalt liner would be required to withstand the tensile stresses, shear stresses, and hydrostatic pressure of the tailings impoundment. 0xidation, and the resulting loss of flexibility, of the thin membrane is also a potential failure mechanism. The oxidized asphalt could delaminate with the fabric, resulting in the failure mechanisms outlined above. Also, the asphalt emulsion can be applied only at temperatures above freezing.

Asphalt Concretes

Paving Concrete

Asphaltic compositions of this category are designed for roadway constructions. Typically, paving concrete consists of 4 to $6 \mathrm{wt} \%$ asphalt, the 
remainder carefully graded aggragate. Rubber is occasionally added to the asphalt to decrease the effect of temperature of the asphalt properties. Because these concretes are designed for traffic use, they include $\sim 6$ to 10 vol\% voids to allow for motion of the concrete under the pressure exerted by vehicular traffic without cracking the pavement. Because of the relatively high voids content and the failure of this style of liner reported by Haxo and White (1976a) after exposure to landfill leachate for $1 \mathrm{yr}$, the liner study gave this material no further consideration.

\section{Hydraulic Asphalt Concrete}

Hydraulic concretes are similar to paving concretes but the asphalt content is increased to 6 to $10 \%$ (Middlebrooks et a1. 1978), the voids reduced to $<4 \%$, and the aggregate changed to contain smaller, more rounded rock and minera] fill. Permeabilities to $10^{-10} \mathrm{~cm} / \mathrm{s}$ are reported for these materials (Stewart 1978; Hickle 1976). To prevent seepage through these liners, they are laid in two lifts, and the joints are staggered from 2 to $6 \mathrm{ft}$. Hydraulic concretes passed a year-exposure test to landfill leachate conducted by Haxo and White (1976a).

\section{Asphalt/Rubber Admixture}

Aspha]t/rubber admixture is a newly developed type of liner constructed of asphalt and graded rubber particles from discarded tires mixed in a composition of $75 \%$ aspha1t, $25 \%$ rubber. The advantages of this material include the effects of rubber on asphalt discussed above. The aggregate is an elastometer that allows the membrane to deform more than rock aggregate concretes. Volume changes during freeze/thaw of the liner due to the water absorbed by the rock aggregate are eliminated. Frobel et al. (1977) have used this material at an application rate of $4.5 \mathrm{~L} / \mathrm{m}^{2}$ and report satisfactory results. Permeability is $10^{-7} \mathrm{~cm} / \mathrm{s}$, although experimental error is suspected and the permeability may be lower.

\section{Soil Asphait}

Soil asphalts consist of local sands and an asphalt mixed in a composition of $\sim 94 \%$ sand, $6 \%$ asphalt. These materials are not acceptable for this 
application due to high permeability, $10^{-3} \mathrm{~cm} / \mathrm{s}$ (Haxo 1976a). This high permeability is caused by the similar size of the aggregate material complicating the compaction, thus leaving a significant void content. Haxo and White (1976a) report failure of a soil asphalt membrane exposed to landfill leachate for $1 \mathrm{yr}$.

\section{CONCRETES}

Portland cement-based concretes have long been used for lining various water impoundment $f$ acilities, but these admixtures exhibit several limitations when considered for this application. These concretes are inherently susceptible to spall damage from exposure to freeze/thaw cycling, cracking due to the volume changes experienced under repeated wetting and drying, and corrosion from the $\mathrm{SO}_{4}{ }^{-2}$ ions present in several of the tailings leachate. They would require reinforcement if installed where significant substrate subsidence is expected. Water permeability of these concretes are on the order of $10^{-4} \mathrm{~cm} / \mathrm{s}$.

For tailings impoundments where $\mathrm{SO}_{4}^{-2}$ ions are not present, little ground motion is expected, annual precipitation is small, and subgrade water content is nearly constant, concretes which have been developed for use on bride decks could be considered as liner materials. These concretes were developed to minimize damage from freeze/thaw cycling and to protect the steel reinforcement structure from corrosion by de-icing chemicals. These specialized concretes are termed "internally sealed concrete," "polymer-impregnated concrete," "polymer-portland cement concrete," and "polymer concrete." However, since these materials have not been developed for large-scale use in ponds and because of the strength and cracking limitations described below, none of these special concretes could be considered for laboratory testing.

Internally Sealed Concretes

Internally sealed concretes (ISC's) are admixtures of portland cement, aggregate, and wax spheres. After the concrete is cast and partially cured, heat is applied to the top surface, melting the wax. Ideally, this seals the inherent interconnected pores in the paving. Typical specifications for these admixtures are presented in Table 4. 


\section{TABLE 4. Internally Sealed Concrete Specification}

\begin{tabular}{|c|c|}
\hline Item & Specification \\
\hline Admix Density & $446 \mathrm{~kg} / \mathrm{m}^{3}$ \\
\hline Aggregate Content & 60 Volume $\%$ \\
\hline Wax Content & 7.8 volume $\%$ \\
\hline Entrained Air & 4 to 6 volume $\%$ \\
\hline Water-Cement Ratio & 0.47 \\
\hline \multirow{5}{*}{$\begin{array}{l}\text { Wax Specifications } \\
\text { - Density-- } \\
\text { - Sphere Size-- } \\
\text { - Wax-- }\end{array}$} & \\
\hline & $60 \mathrm{~kg} / \mathrm{m}^{3}$ \\
\hline & $-20+80$ Mesh \\
\hline & 75\% Parrafin \\
\hline & $25 \%$ Mortan \\
\hline
\end{tabular}

During the concrete curing, electrical heaters are placed on the surface of the concrete to melt the wax. It is recommended that the minimum temperature in the concrete during the heat treatment be above $85^{\circ} \mathrm{C}$ to achieve the best results.

Among the concerns of this concrete sealing mechanism are the stresses induced by the thermal gradients present in the concrete, and by the thermal expansion differences between the cement paste and the aggregate. To minimize the latter stresses, limestone aggregate is recommended. However, the acidic nature of the tailings leachate would force selection of an alternate material. These concretes demonstrate about $25 \%$ reduced compressive strength (Tyson 1978).

\section{Polymer Impregnated Concrete}

Polymer impregnated concrete (PIC) materials are designed to protect the portland cement from chemical attack, reduce/freeze thaw failure, and to increase the mechanical properties of the concrete. As with ISC's, this is accomplished by filling the pores--in this case with a polymer. The method for forming PIC is as follows:

1. cast the concrete,

2. dry the concrete to reduce water in the concrete pores, 
3. saturate the concrete with a monomer, and

4. polymerize the monomer.

Typically, liquid monomers are used, but gaseous monomers are possible. All cements, aggregates, and admixes are compatible with this technique.

The strength and durability of this compound is clearly a function of the percentage of concrete voids filled with the polymer--or rephrased, a function of the amount of water removed from the cast concrete. This requires that the concrete be heated, complicating the process for large applications.

Three methods of polymerizing the monomer are suggested. These inciude thermal-catalytic polymerization, promoted-catalytic polymerization, and exposure to gamma radiation from a cobalt-60 source. The first method requires that heat be applied to the saturated concrete, thus actuating the catalyst compound to polymerize the monomers. The promoted-catalytic method is similar but takes place at ambient temperature.

Limitations of this concrete compound include:

- saturating the sloped concrete sections with the low-viscosity monomer solution;

- inhomogeneities in the polymer coating;

- stresses induced in polymers caused by the inherent volume reduction during polymerization;

- cracks forming in the concrete after the treatment that would expose untreated concrete to the tailings leachate.

These compounds are reported to have permeabilities on the order of $10^{-10} \mathrm{~cm} / \mathrm{s}$ (Hoff 1977).

Polymer-Portland Cement Concrete

Polymer-portland cement concrete (PPCC) compounds are designed to improve the same characteristics of portland concretes as PIC as well as the concrete shear bond, bond to aggregate, tensile strength, and flexural strength. Unlike PIC, the polymeric materials are included in the cement/aggregate admixture 
prior to casting. Two types of PPCC are considered: PPCC utilizing premix polymers and postmix polymers.

Premix PPCC is the most common form. In this case, the monomers have been polymerized prior to addition to the concrete/aggregate admixture. The polymers are generally added as latexes or polymer dispersions and result in distinct polymeric phases in the concrete formed. These compounds are moistcured for 1 to $3 \mathrm{~d}$ and then allowed to dry under ambient conditions. Because the polymers are generally added as water soluble compounds during the concrete mixing, prolonged contact with water leads to the dispersion of the polymer. This eventually would result in a porous concrete with properties similar to plain portland cement concrete.

Limited success has been achieved with postmix PPCC. The problems encountered include interference with portland cement hydration, chemical reactions between the cement and monomer, difficulty in producing a homogeneous monomer dispersion, poor bonds between the polymer and aggregate, and achieving complete polymerization (Hoff 1977).

\section{Polymer Concrete}

Polymer concretes ( $P C^{\prime} s$ ) are the most promising of the nonasphaltic concretes considered. $A P C$ is a polymer-aggregate admixture and utilizes the same mixing and installation equipment as portland cement concretes; exhibit much greater chemical stability, compressive and tensile strengths and freeze/thaw resistance than portland cement concretes; and should exhibit very low permeabilities (Hickey 1969; Hoff 1977).

These concretes are made with a variety of resins or monomers and thus can be adapted to the service required. The aggregates should be dried to less than 2\% moisture for best service. PC's contain between 5 and $30 \mathrm{wt} \%$ monomer. The catalyst-promoter polymerization technique described in the PIC section is recommended (Hoff 1977).

\section{PRESSURE GROUTING FOR LINER FORMATION}

The possibility of creating an effective candidate liner for uranium-mill tajlings leachate by injecting portland cement or epoxy-based grouts into the 
subgrade was evaluated for this report. Pressure grouting, as this technique is known, has been used extensively in the mining industry for reduction of water flow into a mine, for sealing horizontal methane-drainage holes in coal mines, sealing of the boreholes created during proposed subsurface high-level nuclear-waste disposal, and to stabilize geological formations (Aul and Cervik 1976; Anonymous 1969a, 1969b; Gulick et a1. 1980).

Pressure grouting is performed by creating small boreholes in the area to be grouted, sealing a grout injection line in the borehole, and injecting the grout until either 1) the injection pressure reaches some predetermined level (generaliy the maximum pump head), or 2) the grout is seen returning to the surface through cracks near the borehole (Anonymous 1969a).

Although pressure grouting is satisfactory for the majority of uses outlined above, relying on this method to seal a tailings impoundment is impractical. This conclusion is supported by numerous observations in the literature regarding test cores or excavation at a grouted area. These reports refer to areas of extensive cracking with very few cracks containing grout, locations where the grouting was ineffectual because of high ground-water content that prohibited curing of the grout, and repeated instances of inhomogeneous distribution of the grout (Aul and Cervik 1976; Anonymous (1969a, 1969b).

\section{POLYMERS}

Polymeric materials were considered in this study. These flexible lining materials can be generally classified as elastomers (rubbers) or plastics. The major advantages of these materials are their low permeability and ability to conform to changing substrate conditions due to freeze/thaw or wet/dry cycling, sink-hole formation, subsidence, etc. The liners are delivered as large sheets, usually containing several factory seams, and are generally available in a variety of thicknesses, colors, with or without fiber reinforcement (scrim), and of special compositions to modify the basic polymer to meet the specific exposure conditions (Stewart 1978).

These materials require particular care in relation to site selection, ground preparation and installation. To maximize the potential effectiveness 
of the liner, minimization of potential liner compromising mechanisms is of primary interest. These mechanisms include damage by animals or microbes; operation of heavy equipment on the liner; poor seaming technique; exceeding of the tensile capabilities of the material during installation or by subsequent ground subsidence; perforation by growing plants or sharp objects beneath the iiner; potential buildup of gas pressure beneath the liner by various means; and excessive reverse hydrostatic pressure caused by a high water table (Williams 1978; Stewart 1978; Du Pont A; Du Pont C).

Proper design of the tailings impoundment can reduce these potential failure modes. Placing a $15-$ to $30-\mathrm{cm}$ layer of sandy soil or tailings over the liner will protect it from damage by equipment or animal trespass, and would be required for ozone or ultraviolet-sensitive polymers. Biocides or fungicides should be incorporated into the liner during initial processing to protect the liner from microbial attack, and no liner polymer should be selected which would nourish microbes. Seams created in.the field are less reliable than seans by the supplier and should be kept to a minimum. The liner selected should demonstrate good field-seaming characteristics, and each joint should be checked by conventional techniques.

The liner can be protected from over-stressing by a number of techniques. These include compacting the ground beneath the liner to prevent sink-hole formation; ensuring that the liner is not stretched during installation; purchasing the liner with internal fabric reinforcement (scrim); and limiting the slope of the impoundment walls to $1 \mathrm{~m}$ vertical to $2 \mathrm{~m}$ horizontal. For similar reasons it is recommended that any seams on the walls be oriented so that the seams run vertically (Schultz and Miklas 1980).

In addition to precompaction, several other preparations are required prior to liner installation. The ground must be sterilized to prevent vegetation from penetrating the liner, and all organic materials must be removed to prevent gas-bubble formation beneath the liner. In areas where high winds or widely fluctuating water tables are expected, vents and sloped pond bottoms as well as scrims are recommended to prevent damage from gas accumulation 
(Lubina, Hovater and McCready 1979; Du Pont C). Scrims are also recommended when high water tables $c$ an result in excessive hydrostatic pressures beneath the liner.

\section{Elastomers}

\section{Butyl Rubber}

Butyl rubber is a polymer containing $297 \%$ isobutylene and $3 \%$ isoprene. This material has demonstrated lifetimes in excess of $20 \mathrm{yr}$ lining potable water reserviors (Stewart 1978). Butyl rubber has good weathering resistance, is serviceable between -7 and $120^{\circ} \mathrm{C}$, will elongate in excess of $300 \%$ and recover in this temperature range, has low water absorption and permeability $\left(1.1 \times 10^{-11} \mathrm{~cm} / \mathrm{s}\right.$ ) (Haxo 1976a), and is available from 0.5- to $3.2-\mathrm{mm}$ (20- to 125-mil) thickness, with or without scrim (Stewart 1978; Williams 1978; Haxo 1976a). Haxo et al. (1979) demonstrated that the properties of butyl changed little when the material was exposed to 1 andfill leachate for 8 mo (Table 5). The results of preliminary tests with a $\mathrm{HNO}_{3}$ solution $(1.5 \mathrm{pH})$ are shown in Table 6 (Haxo et al. 1977; Haxo et al. 1979; Haxo 1976b). However, the material has low resistance to hydrocarbons, requires a difficult, two-part seaming

TABLE 5. Summary of the Effects of Immersion of Polymeric Membrane Liners in Leachate for Eight Months

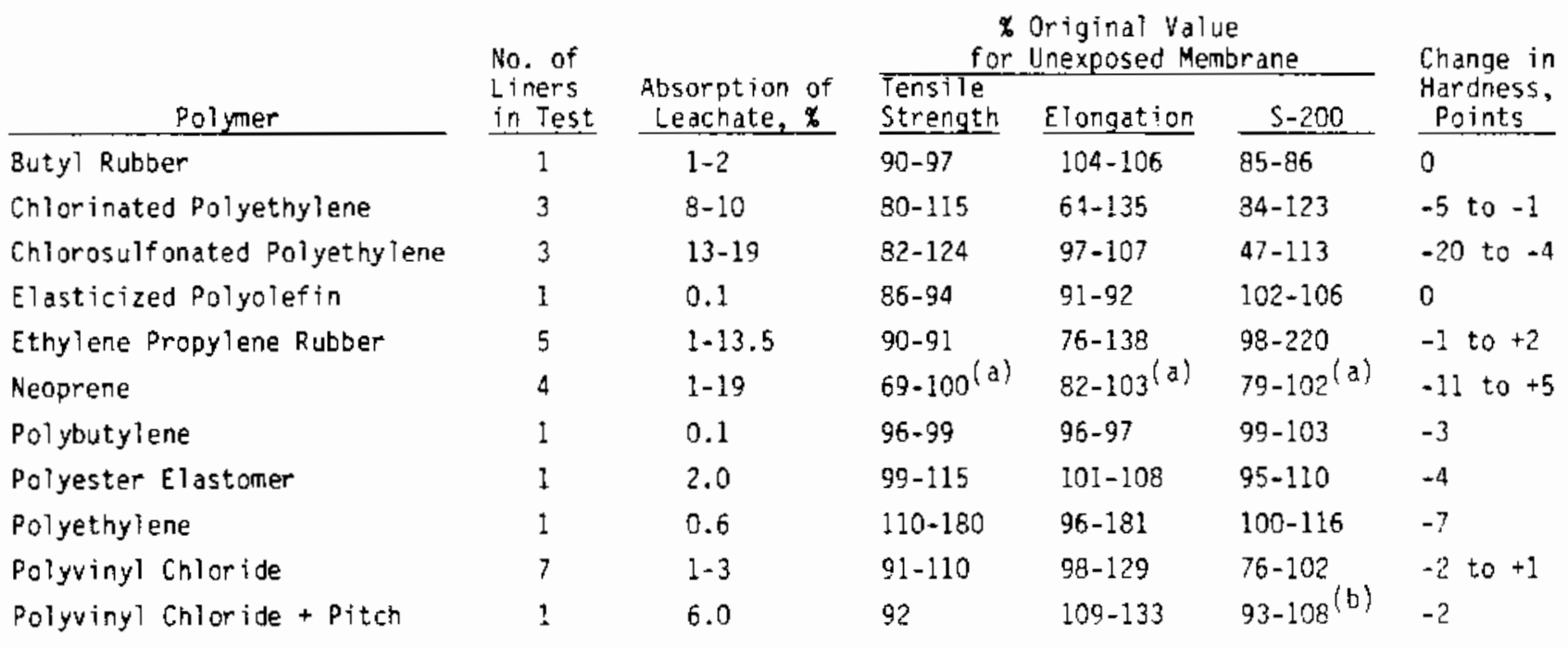

(a) Data on fabric-reinforced neoprene liner \$42 were not included.

(b) S-100 - unexposed specimen broke at $150 \%$ elongation. 
TABLE 6. Effect of Immersing Liner and Sealing Materials in Hazardous Wastes--A Preliminary Study

(Unit: Increase in Area of Portion of Strip Immersed)

\begin{tabular}{|c|c|c|c|c|c|c|c|c|c|c|c|c|}
\hline I tem & $\begin{array}{r}\text { Identi- } \\
\text { fication } \\
\text { Number } \\
\end{array}$ & $\frac{\text { Strong }}{\underline{H F L(a)}}$ & $\frac{\mathrm{Acid}}{\mathrm{HNO}_{3}(\mathrm{bT})}$ & \multicolumn{2}{|c|}{$\frac{\text { Strong Base }}{\text { Slop Spent }}$} & $\begin{array}{l}\text { Tank } \\
\text { "ween } \\
\text { oi\}"(a) }\end{array}$ & \multicolumn{2}{|c|}{$\begin{array}{l}\text { ottor } \\
\text { Tergol } \\
\text { Clay }\end{array}$} & $\frac{\text { Load }}{\text { Low Po }}$ & $\begin{array}{l}\text { stes } \\
\text { Gasoline } \\
\text { Wash } \\
\text { Water }\end{array}$ & $\begin{array}{c}\text { Sat. \& } \\
\text { Unsit. } \\
\text { oiln(e) }\end{array}$ & $\begin{array}{c}\text { Pesticide } \\
\text { Weed } \\
\text { Killer }\end{array}$ \\
\hline Polyvinyl Chlaride (PVC) & $\begin{array}{l}10 \\
11 \\
17 \\
40 \\
\text { RN } 49 \\
59 \\
67 \\
\text { RN } 71\end{array}$ & $\begin{array}{l}C C \\
\text { NVC } \\
\text { NVC } \\
\text { NVC } \\
-\cdots \\
\text { NWC } \\
\text { NWC } \\
\text { NVC }\end{array}$ & $\begin{array}{l}\text { NVC } \\
\text { NVC } \\
\text { NVC } \\
\text { NVC } \\
\text { NVC } \\
\text { NVC } \\
(g)\end{array}$ & $\begin{array}{l}\text { HDS } \\
\text { HDS } \\
\text { HDS } \\
\text { HOS } \\
-- \\
\text { HDS } \\
\text { HDS } \\
\text { HOS }\end{array}$ & $\begin{array}{l}\text { NWC } \\
\text { NVC } \\
\text { NVC } \\
\text { NVC } \\
-- \\
\text { NVC } \\
\text { NVC } \\
\text { NVC }\end{array}$ & $\begin{array}{l}\text { NVC } \\
N V C \\
+11 \\
+24 \\
+3 \\
+26 \\
+5 \\
C C\end{array}$ & $\begin{array}{l}\text { HDS, } \\
\text { HDS, } \\
\text { HDS, } \\
\text { SHD } \\
- \\
\text { SHD, } \\
\text { HOS, }\end{array}$ & $\begin{array}{l}-6 \\
-6 \\
-8\end{array}$ & $\begin{array}{l}\text { NVC } \\
\text { NVC } \\
N V C \\
\text { NVC } \\
-\cdots \\
\text { NVC } \\
N V C \\
\text { NVC }\end{array}$ & \begin{tabular}{l} 
NVC \\
NVC \\
NVC \\
NVC \\
\hdashline- \\
NVC \\
NVC \\
NVC
\end{tabular} & $\begin{array}{ll}\text { HOS, } & -10 \\
\text { HOS, } & -5 \\
\text { HOS, } & -6 \\
\text { SHD } & \\
-- & \\
\text { SHD } & \\
\text { SHD } & \\
\text { HDS, } & -6\end{array}$ & $\begin{array}{l}\text { NWC } \\
\text { NVC } \\
\text { NWC } \\
\text { NWC } \\
\text { NWC } \\
\text { NWC } \\
\text { NUC }\end{array}$ \\
\hline Clorosulf onated Polyethylene & $\begin{array}{l}R N 6^{(f)} \\
R C 50 \\
55\end{array}$ & $\begin{array}{l}\text { NVC } \\
-\cdot- \\
\text { NVC }\end{array}$ & $\begin{array}{l}\text { NVC } \\
\cdots \cdot- \\
\text { NVC }\end{array}$ & $\begin{array}{l}\text { NWC } \\
\ldots W \\
\text { NVC }\end{array}$ & $\begin{array}{l}\text { NWC } \\
\text { NWC }\end{array}$ & $\begin{array}{r}\text { RVD } \\
6 \\
-\end{array}$ & $\begin{array}{l}\text { NWC } \\
\cdots- \\
\text { NWC }\end{array}$ & & $\begin{array}{l}\text { NVC } \\
-:- \\
\text { NVC }\end{array}$ & $\begin{array}{l}\text { NVC } \\
\cdots \cdot- \\
\text { NVC }\end{array}$ & $\begin{array}{l}40 \\
36\end{array}$ & $\begin{array}{l}\text { NuC } \\
-\cdots \\
---\end{array}$ \\
\hline Chlorinated Polyethylene (CPD) & $\begin{array}{l}12(f) \\
38 \\
\text { RN } 39 \\
\text { RP } 48 \\
\text { RP } 73\end{array}$ & $\begin{array}{l}\text { NWC } \\
\text { NVC } \\
\text { NVC } \\
--- \\
\text { NVC }\end{array}$ & $\begin{array}{l}\text { NVC } \\
\text { NVC } \\
\text { NVC } \\
-\therefore \\
\text { NVC }\end{array}$ & $\begin{array}{l}\text { NVC } \\
\text { NVC } \\
\text { NVC } \\
\cdots \\
\text { NWC }\end{array}$ & $\begin{array}{l}\text { NWC } \\
\text { NWC } \\
\text { NWC } \\
-- \\
\text { NWC }\end{array}$ & $\begin{array}{l}\text { RVD } \\
\text { RVO 92 } \\
\text { RVD } \\
\text { RVD (h) } \\
---\end{array}$ & $\begin{array}{c}6 \\
\text { NWC } \\
\text { NWC } \\
-2 \\
\text { NWC }\end{array}$ & & $\begin{array}{l}\text { NVC } \\
N V C \\
\text { NVC } \\
\cdots- \\
B L S\end{array}$ & $\begin{array}{l}\text { NWC } \\
\text { NWC } \\
\text { NWC } \\
-\cdots+ \\
\text { NVC }\end{array}$ & $\begin{array}{c}11 \\
16 \\
9 \\
-\overline{C C}, 2\end{array}$ & $\begin{array}{l}\text { NidC } \\
\text { NWC } \\
\text { NWC } \\
\text { NYC } \\
\cdots\end{array}$ \\
\hline Palychloroprene (Neoprene) & 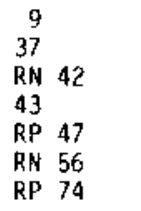 & $\begin{array}{l}C C \\
\text { NVC } \\
\text { NVC } \\
--. \\
-- \\
\text { NVC } \\
\text { NVC }\end{array}$ & $\begin{array}{l}\text { SCR } \\
\text { NVC } \\
\text { RVD } \\
-- \\
\text { NVC } \\
\text { NVC }\end{array}$ & \begin{tabular}{l} 
CC \\
NVC \\
NWC \\
\hdashline- \\
SHO \\
(h)
\end{tabular} & $\begin{array}{l}\text { NVC } \\
\text { NWC } \\
\text { NWC } \\
--- \\
-- \\
\text { NWC } \\
\text { NVC }\end{array}$ & $\begin{array}{r}111 \\
67 \\
\text { REV } \\
10 \\
6 \\
100 \\
\text { NVC }\end{array}$ & $\begin{array}{c}77 \\
\text { NWC } \\
\text { NWC } \\
13 \\
- \\
3 \\
\text { NWC }\end{array}$ & & $\begin{array}{l}\text { NVC } \\
\text { NVC } \\
\text { NVC } \\
-- \\
--- \\
\text { NVC } \\
\text { NVC }\end{array}$ & $\begin{array}{l}\text { NWC } \\
\text { NWC } \\
\text { NVC } \\
--- \\
-- \\
\text { NWC } \\
\text { NVC }\end{array}$ & $\begin{array}{c}42 \\
21 \\
5 \\
48 \\
-10 \\
10 \\
\text { NVC }\end{array}$ & $\begin{array}{l}--- \\
\text { NVC } \\
\text { NiC } \\
\text { NVC } \\
--- \\
\text { NVC } \\
--\end{array}$ \\
\hline
\end{tabular}




\section{TABLE 6. (contd)}

(Unit: $x$ Increase in Area of Portion of Strip Immersed)

\begin{tabular}{|c|c|c|c|c|c|c|c|c|c|c|c|}
\hline \multirow[b]{2}{*}{ Item } & \multirow[b]{2}{*}{$\begin{array}{r}\text { Jdenti- } \\
\text { fication } \\
\text { Number } \\
\end{array}$} & \multirow[b]{2}{*}{$\begin{array}{l}\text { Strong } \\
\mathrm{FL}(\mathrm{a})\end{array}$} & & \multicolumn{2}{|c|}{ Strong Base } & \multicolumn{2}{|c|}{ Tank Bottom } & \multicolumn{2}{|c|}{ Load Wastes } & \multirow[b]{2}{*}{$\begin{array}{c}\text { Sat. \& } \\
\text { Unsat } \\
\text { Qi\}" (e) }\end{array}$} & \multirow[b]{2}{*}{$\begin{array}{l}\text { Pesticide } \\
\text { Weed } \\
\text { Killer }\end{array}$} \\
\hline & & & & $\begin{array}{l}\text { Stro } \\
\text { Slop } \\
\text { Water }\end{array}$ & $\begin{array}{l}9 \text { Base } \\
\text { Spent } \\
\text { Caust ic } \\
\end{array}$ & $\begin{array}{l}\text { Jank } \\
\text { "Weed } \\
\text { Oi1"(a) }\end{array}$ & $\begin{array}{c}\text { Bottom } \\
\text { Tergol } \\
\text { Clay } \\
\end{array}$ & $\begin{array}{r}\text { Low } P(d) \\
\text { Washing }\end{array}$ & $\begin{array}{l}\text { Gasoline } \\
\text { Wash } \\
\text { Water }\end{array}$ & & \\
\hline Butyl Rubber & $\begin{array}{l}22 \\
24 \\
44 \\
\text { RN } 57(f)\end{array}$ & $\begin{array}{l}\text { NVC } \\
\text { NYC } \\
-- \\
\text { NYC }\end{array}$ & \begin{tabular}{l} 
NVC \\
NVC \\
\hdashline NVC
\end{tabular} & \begin{tabular}{l} 
NVC \\
NVC \\
\hdashline-- \\
NVC
\end{tabular} & $\begin{array}{l}\text { NVC } \\
\text { NVC } \\
\cdots V C\end{array}$ & $\begin{array}{l}69 \\
91 \\
76 \\
67\end{array}$ & $\begin{array}{l}64 \\
59 \\
13 \\
20\end{array}$ & $\begin{array}{l}\text { NVC } \\
\text { NVC } \\
--- \\
\text { NVC }\end{array}$ & $\begin{array}{l}\text { NVC } \\
\text { NVC } \\
-:- \\
\text { NVC }\end{array}$ & $\begin{array}{l}69 \\
89 \\
94 \\
40\end{array}$ & $\begin{array}{l}\text { WVC } \\
--- \\
--- \\
\text { NVC }\end{array}$ \\
\hline Elasticized Polyolefin & $\begin{array}{l}36 \\
41\end{array}$ & $\begin{array}{l}\mathrm{NVC} \\
\text { NVC }\end{array}$ & $\begin{array}{l}\text { NVC } \\
\text { NVC }\end{array}$ & $\begin{array}{l}\text { NVC } \\
\text { NVC }\end{array}$ & $\begin{array}{l}\text { NUC } \\
\text { NVC }\end{array}$ & $\begin{array}{l}49 \\
42\end{array}$ & $\begin{array}{l}17 \\
18\end{array}$ & $\begin{array}{l}\text { NVC } \\
\text { NVC }\end{array}$ & $\begin{array}{l}\text { NVC } \\
\text { NVC }\end{array}$ & $\begin{array}{l}32 \\
24\end{array}$ & $\begin{array}{l}\text { NVC } \\
\text { NVC }\end{array}$ \\
\hline
\end{tabular}

(a) Hydrofluoric

(c) "Weed oil" (highly aromatic) 30x; water $70 x$ (tank bottom waste).

(c) "Wheed oil" (highly aromat

(d) Low-lead gas was

(e) Matertals incorporated in cells.

g) 0.10 in. swell in each direction, curled, and delaminated.

h) Conplete loss of tear strength.

(i) Neoprene in satisfactory condition but reinforcing fabric (polyester) dissolved.

(j) $B 1$ ack rubs off, indicating possible dissolving of the liner.

\section{ABBREVIATIONS:}

ABS - Absarbed waste

BLS - Blistering of surface

CC - Color change

DEL - Delaninated

DIS - Dissolved or disintegrated

\section{ABBREVIATIONS (contd):}

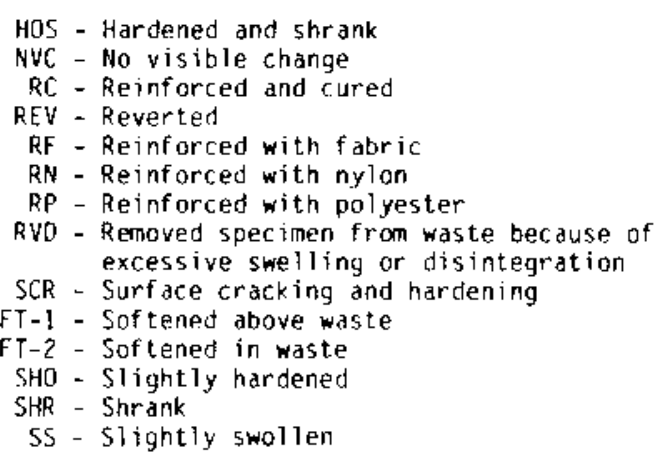


procedure that is very weather dependent, and is less resistant to embrittlement by radiation damage than other elastomers considered. The pertinent characteristics of butyl rubber are presented in Table 7. Other elastomeric materials exist that have improved characteristics when exposed to conditions expected in a uranium-mill tailings repository.

\section{Ethylene Propylene Rubber (EPDM, Nordel)}

Ethylene propylene rubber is a diene monomer similar to butyl rubber. Nordel is resistant to ozone and UV attack, is serviceable over -50 to $+100^{\circ} \mathrm{C}$ temperature range, and is not susceptible to damage from microbial attack. Nordel is available with or without scrim and in 20- to 60-mil thicknesses (Du Pont A, B and C; Willians 1978). Although Nordel exhibits superior durability with hydrocarbons than butyl rubber, it is not recommended for this service (Du Pont A). EPDM is slightly less resistant to radiation damage than hypalon (Mattia and Luh 1971) discussed in the following section. As with all vulcanized materials, Nordel presents seaming difficulties. Haxo et al. (1979) showed Nordel to be affected, more than butyl rubber, by landfill leachate (see Table 5), and they report a significant loss of transverse flexibility during the exposure period. Properties of unexposed EPDM are listed in Table 4.

\section{Chlorosulf onated Polyethylene}

Chlorosulfonated polyethylene (CSPE) (also called hypalon) is obtained by the reaction of polyethylene in solution with chlorine and sulfur dioxide. When delivered to the installation site, hypalon exhibits properties associated with plastics and self-vulcanizes upon exposure to ultraviolet radiation and soil moisture. The product has these characteristics:

- is resistant to both ozone and ultraviolet light (UV);

- is very impermeable to water $\left(3.6 \times 10^{-12} \mathrm{~cm} / \mathrm{s}\right.$ for a $34-m i 17$ iner $)$;

- performs satisfactorily from -18 to $120^{\circ} \mathrm{C}$;

- is readily seamed under wet conditions;

- resists microbial attack; 
TABLE 7. Properties of Polymeric Liner Membranes Installed as Barriers

Cell Number

Liner Number

Material

Thickness, mm (0.001 in.)

Coefficient of Water Per-

meability, cm/s

Water Absorption, $x$

2 h $100^{\circ} \mathrm{C}$

$7 \mathrm{~d}$ e $25^{\circ} \mathrm{C}$
$70 \mathrm{~d}$ o $25^{\circ} \mathrm{C}$

0.38

Puncture Test, (a) $25 \mathrm{~mm} / \mathrm{min}$,

$\max$. force, $N(1 b)$

elongation, mo (in.)

$\infty$

Puncture Test, $500 \mathrm{~mm} / \mathrm{min}$, max. force, $N(1 b)$ elongation, $\min (i n$.

\section{$61.9(13.9)$}

$19(0.76)$

$\begin{array}{rr}115 & (25.8) \\ 18 & (0.69)\end{array}$

$2.73(15.6)$

peel, $\mathrm{kN} / \mathrm{m}$ ( $\mathrm{b} / \mathrm{in}$.

shear, $\mathrm{kN} / \mathrm{m}(\mathrm{lb} / \mathrm{in}$.

$3.54(20.2)$

$0.70(4.0)$

81
76

Shore

$10 \mathrm{~s}$

Grain Oirection

Modulus $100 x$,

(1b/in. ${ }^{2}$ )

$7.3 \times 10^{-13}$

98

With

Cross

With

8.76
$(1270)$

$\left(\begin{array}{l}7.10 \\ (1030)\end{array}\right.$

8.69

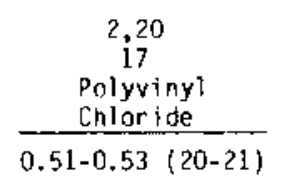

$\begin{array}{cc}3,21 & 4,22 \\ 7 & 6\end{array}$

Butyl Rubber

Hypalon, with

16
16
Ethylene-prop

5,23
16

diente-propylene-

diene (EPOM) Rubber

$1.1 \times 10^{-11}$

$3.6 \times 10^{-12}$

$2.3 \times 10^{-11}$

7.17
2.04

0.17
0.18

0.18
0.52

$149(33.5)$

$29(1.14)$

$199(44.8)$
$31(1.22)$

$0.66(3.8)$

$5.25(30)$

55
51

Cross

With Cross

7.79

4.52

0.47
0.61

0.61
1.90

131
26 $(29.5)$

$141(31.6)$
$35(1.38)$

(4.

$175(39.4)$

$15(0.60)$

$37(1.44)$

$5.25(30)$
$8.75(50)$

$0.44(2.5)$
2.56

81
79

57
54

with

Cross

with

Cross

$2.41 \quad 2.02$

$6.90 \quad 5.93 \quad 2.41$

$? .41$

6,24
12

Chlorinated Polethylene

$2.0 \times 10^{-12}$

2.93

1.43
5.31

$150(33.8)$

209
$26(47.0)$

$1.75(10)$
$9.98(57)$

85
87

With

Cross

8.41

3.59 


\section{TABLE 7. (contd)}

\begin{tabular}{|c|c|c|c|c|c|c|c|c|c|c|c|c|}
\hline \multirow{2}{*}{$\begin{array}{l}\text { Cell Number } \\
\text { Liner Number } \\
\text { Material } \\
\text { Modulus } 200 x \text {, } \\
\quad \text { MPa } \\
\quad\left(1 b / i n .^{2}\right)\end{array}$} & \multicolumn{2}{|c|}{$\begin{array}{c}1,19 \\
21 \\
\text { Polyethylene }\end{array}$} & \multicolumn{2}{|c|}{$\begin{array}{l}2,20 \\
\text { i7 } \\
\text { Polyvinyl } \\
\text { Chloride } \\
\end{array}$} & \multicolumn{2}{|c|}{$\begin{array}{r}3,21 \\
7 \\
\text { tyl Rubber }\end{array}$} & \multicolumn{2}{|c|}{$\begin{array}{c}4,22 \\
6 \\
\text { Hypalon, with } \\
\text { Nylon Scrim }\end{array}$} & \multicolumn{2}{|c|}{$\begin{array}{c}5,23 \\
16 \\
\text { Ethyl ene-propylene- } \\
\text { diene (EPDM) Rubber }\end{array}$} & \multicolumn{2}{|c|}{$\begin{array}{c}6,24 \\
12 \\
\text { Chlorinated } \\
\text { Polethylene } \\
\end{array}$} \\
\hline & $\begin{array}{c}10.1 \\
(1470)\end{array}$ & $\begin{array}{c}7.24 \\
(1050)\end{array}$ & $\begin{array}{c}14.3 \\
(2080)\end{array}$ & $\begin{array}{l}12.8 \\
(1850)\end{array}$ & $\begin{array}{l}5.31 \\
(770)\end{array}$ & $\begin{array}{l}4.21 \\
(610)\end{array}$ & $\begin{array}{c}11.8 \\
(1710)\end{array}$ & $\begin{array}{c}9.17 \\
(1330)\end{array}$ & $\begin{array}{l}5.24 \\
(760)\end{array}$ & $\begin{array}{l}5.24 \\
(760)\end{array}$ & $\begin{array}{c}12.5 \\
(1820)\end{array}$ & $\begin{array}{l}5.79 \\
(840)\end{array}$ \\
\hline $\begin{array}{l}\text { Modulus a } 300 x \text {, } \\
\text { MPa } \\
\left.\text { (ib/in. }{ }^{2}\right)\end{array}$ & $\begin{array}{c}11.6 \\
(1680)\end{array}$ & $\begin{array}{l}7.72 \\
(1120)\end{array}$ & & & $\begin{array}{c}8.48 \\
(1230)\end{array}$ & $\begin{array}{c}6.90 \\
(1000)\end{array}$ & & & $\begin{array}{l}7.72 \\
(1120)\end{array}$ & $\begin{array}{c}7.72 \\
(1120)\end{array}$ & $\begin{array}{c}17.0 \\
(2460)\end{array}$ & $\begin{array}{l}8.27 \\
(1200)\end{array}$ \\
\hline $\begin{array}{l}\text { Tensile Strength, } \\
\text { MPa } \\
1 \mathrm{~b} / \text { in. }^{2}\end{array}$ & $\begin{array}{c}11.7 \\
(1700)\end{array}$ & $\begin{array}{c}17.9 \\
(2590)\end{array}$ & $\begin{array}{c}18.2 \\
(2640)\end{array}$ & $(2520)$ & $\begin{array}{c}9.93 \\
(1440)\end{array}$ & $\begin{array}{c}9.86 \\
(1430)\end{array}$ & $\begin{array}{c}13.2 \\
(1920)\end{array}$ & $\begin{array}{l}11.1 \\
(1610)\end{array}$ & $\begin{array}{l}10.4 \\
(1510)\end{array}$ & $\begin{array}{c}9.93 \\
\{1440\}\end{array}$ & $\begin{array}{c}17.0 \\
(2460)\end{array}$ & $\begin{array}{l}14.3 \\
(2080)\end{array}$ \\
\hline $\begin{array}{l}\text { Elongation, } x \\
\text { Set, } z\end{array}$ & $\begin{array}{l}320 \\
177\end{array}$ & $\begin{array}{l}690 \\
667\end{array}$ & $\begin{array}{r}270 \\
68\end{array}$ & $\begin{array}{r}290 \\
77\end{array}$ & $\begin{array}{r}360 \\
15\end{array}$ & $\begin{array}{r}4.30 \\
18\end{array}$ & $\begin{array}{l}250 \\
115\end{array}$ & $\begin{array}{l}250 \\
106\end{array}$ & $\begin{array}{r}420 \\
13\end{array}$ & $\begin{array}{r}400 \\
19\end{array}$ & $\begin{array}{l}300 \\
199\end{array}$ & $\begin{array}{l}520 \\
230\end{array}$ \\
\hline $\begin{array}{l}\text { Tear Resistance, }(b) \\
\text { kN/m } \\
(1 \mathrm{~b} / \mathrm{in.})\end{array}$ & $\begin{array}{l}72.6 \\
(415)\end{array}$ & $\begin{array}{l}63.0 \\
\{360\}\end{array}$ & $\begin{array}{l}61.6 \\
(352)\end{array}$ & $\begin{array}{l}55.5 \\
(317)\end{array}$ & $\begin{array}{l}31.5 \\
(180)\end{array}$ & $\begin{array}{l}31.5 \\
(180)\end{array}$ & $\begin{array}{l}56.0 \\
(320)\end{array}$ & $\begin{array}{l}49.0 \\
(280)\end{array}$ & $\begin{array}{l}31.7 \\
(181)\end{array}$ & $\begin{array}{l}31.7 \\
(181)\end{array}$ & $\begin{array}{l}47.2 \\
(270)\end{array}$ & $\begin{array}{l}42.0 \\
(2.40)\end{array}$ \\
\hline $\begin{array}{l}\text { Creep Test (c) } \\
\text { Load, N } \\
\text { (lb) }\end{array}$ & $\begin{array}{c}7.78 \\
(1.75)\end{array}$ & $\begin{array}{l}7.78 \\
(1.75)\end{array}$ & $\begin{array}{l}14.0 \\
(3.15)\end{array}$ & $\begin{array}{l}12.7 \\
(2.85)\end{array}$ & $\begin{array}{l}14.0 \\
(3.14)\end{array}$ & $\begin{array}{l}12.5 \\
(2.82)\end{array}$ & $\begin{array}{l}25.3 \\
(5.68)\end{array}$ & $\begin{array}{l}29.8 \\
(6.7)\end{array}$ & $\begin{array}{c}8.18 \\
(1.84\}\end{array}$ & $\begin{array}{c}6.89 \\
(1.55)\end{array}$ & $\begin{array}{r}2.22 \\
(5.0)\end{array}$ & $\begin{array}{l}14.1 \\
(3.18)\end{array}$ \\
\hline $\begin{array}{l}\text { - hours to failure } \\
\text { - elongation, } \mathbf{x} \\
\text { - initial stretch. } \\
1 \text { min, } \mathbf{x} \\
\text { - set, } \mathbf{c} \\
\text { - creep, cm/cm, } 100 \mathrm{~h}\end{array}$ & $\begin{array}{l}.72 \mathrm{NF} \\
13.3 \\
5.7 \\
9.5 \\
0.10\end{array}$ & $\begin{array}{l}77 \mathrm{NF} \\
47.6 \\
7.7 \\
19 \\
0.52\end{array}$ & $\begin{array}{l}26 \\
194 \\
73 \\
3.89\end{array}$ & $\begin{array}{r}12 \\
138 \\
51 \\
7.5\end{array}$ & $\begin{array}{l}.94 \mathrm{NF} \\
108 \\
\\
84 \\
5.4 \\
0.23\end{array}$ & $\begin{array}{l}94 \mathrm{NF} \\
111 \\
83 \\
5.2 \\
0.23\end{array}$ & $\begin{array}{l}96 \mathrm{NF} \\
194 \\
15 \\
1.87\end{array}$ & $\begin{array}{c}2.2 \\
253 \\
17 \\
100+ \\
99\end{array}$ & $\begin{array}{l}143 \mathrm{NF} \\
112 \\
79 \\
5.6 \\
0.18\end{array}$ & $\begin{array}{l}143 \mathrm{NF} \\
102 \\
78 \\
4.7 \\
0.14\end{array}$ & $\begin{array}{r}31 \\
186 \\
62 \\
4.5\end{array}$ & $\begin{array}{r}47 \\
344 \\
129 \\
176 \\
3.6\end{array}$ \\
\hline
\end{tabular}


- is resistant to $\mathrm{H}_{2} \mathrm{SO}_{4}$ oxidizing chemicals;

- is moderately good for organics (kerosene may be a problem, however);

- is available in $20,000-\mathrm{ft}^{2}$ rolls 4 to $6 \mathrm{ft}$ wide with or without scrim (Du Pont B; Du Pont C; Haxo 1976a).

The material will burn as long as a heat source is supplied, although the material is self-extinguishing after the source is removed. The portions of the liner to be seamed must be shielded from UV radiation, and the material is relatively weak without fabric reinforcement (Du Pont A; Stewart 1978; Du Pont C). A variety of scrims is available, but polypropylene should be chosen due to its superior acid resistance relative to nylon and polyester. Use of polypropolyene scrim, however, requires an opaque hypalon as it is not UV resistant (Edwald 1973).

Of all the elastomers studied, hypalon demonstrates the best resistance to hardening by exposure to gamma radiation and remains relatively unchanged up to $10^{7} \mathrm{R}$ exposure (Du Pont D). Table 8 presents the effects of gamma radiation on several characteristics of the polymers under consideration (Mattia and Luh 1971).

Haxo and White (1976a) determined that exposure to landfill leachate for $1 \mathrm{yr}$ causes swelling of a hypalon liner and a decrease of the seam-peel resistance (see Table 9). However, the resulting seam-peel strength was on the order of the other polymers tested, and the hypalon seam-shear strength remained among the top. As expected, the preliminary study (reported in Table 6) shows no damage to a hypalon liner exposed to a low pH solution (Haxo 1976b).

Additionally, hypalon was chosen as part of the seepage barrier installed at the Cotter Uranium Mill for tailings impoundment. Lubina, Hovater and McCready (1979) report that Du Pont predicts that more than $40 \mathrm{yr}$ service could be expected from an exposed hypalon liner, and indefinite life if the liner is protected by an earthen layer.

\section{Neoprene}

Neoprene is a chlorine-containing synthetic rubber designed to resist hydrocarbon solvents. Neoprenes are serviceable from $-20^{\circ} \mathrm{C}$ to $90^{\circ} \mathrm{C}$, resist 
TABLE 8. Effect of Gamma Radiation(a) on Physical Properties (Blodgett and Fisher 1969)

$\begin{array}{ll}\omega & 5 \times 10^{5} \\ \omega & 5 \times 10^{6} \\ & 5 \times 10^{7} \\ 1 \times 10^{8}\end{array}$

\section{Original Properties}

\section{$200 \%$ Modulus, psi}

Tensile Strength, psi

Elongation at Break,
2006 Modulus, $x$ Retention After Irradiation, Rads

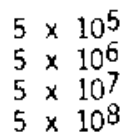

$5 \times 107$

$5 \times 10^{8}$

Tensile Strength, $\%$ Retention After Irradiation, Rads \begin{tabular}{c} 
High \\
Density \\
PVC $\quad$ PE \\
\hline
\end{tabular}

Black Unfilled

$\begin{array}{rrrr}2415 & 1000 & 1767 & 1260 \\ 2601 & 2213 & 2045 & 2272 \\ 250 & 640 & 270 & 480\end{array}$

SBR EPOM EPM Butyl

Silicone

$\begin{array}{rrrr}580 & 1033 & 730 & 520 \\ 1520 & 1443 & 872 & 798 \\ 460 & 470 & 300 & 450\end{array}$

Neoprene

Hypalon

Chlorinated PE

Elongation, $*$ Retention After Irradiation, Rads

$$
\begin{aligned}
& 5 \times 10^{5} \\
& 5 \times 10^{6} \\
& 5 \times 10^{7} \\
& 1 \times 10^{8}
\end{aligned}
$$

$$
\begin{array}{rr}
95 & 125 \\
98 & 115 \\
+ & \\
+ &
\end{array}
$$

859
1191
290

930

2544

$\begin{array}{rr}884 & 626 \\ 2113 & 2170 \\ 560 & 670\end{array}$

(a) Radiation Source - For exposures of $5 \times 10^{5}, 5 \times 10^{6}$, and $5 \times 10^{7}$, cobalt-60 source was used (gama $=1.17$ to 1.332 mev and beta $=0.31 \mathrm{meV}$, at a dose rate of $\left.5 \times 10^{5} \mathrm{rads} / \mathrm{h}\right)$. 'For exposure of $1 \times 10^{8}$, Esso Research and Engineering Company's radiation core in air and water was used, with the same dose rate as above.

Elongated less than $200 \%$

t+ Degraded (10w strength due to chain scissions)

++ Brittle

- No value reported 
TABLE 9. Effect on Properties(a) of Polymeric Membrane Liners of One Year of Exposure to Leachate from Simulated Sanitary Landfills (Date in U.S. Customary Units)

\begin{tabular}{|c|c|c|c|c|c|c|c|}
\hline Item & $\begin{array}{l}\text { Exposure } \\
\text { Time, } \\
\text { Years } \\
\end{array}$ & Polyethylene & $\begin{array}{l}\text { Polyvinyl } \\
\text { Chloride }\end{array}$ & Butyl & $\begin{array}{c}\text { Chloro- } \\
\text { sulfonated } \\
\text { Polyethylene }\end{array}$ & $\begin{array}{l}\text { Ethylene } \\
\text { Propylene } \\
\text { Rubber } \\
\end{array}$ & $\begin{array}{l}\text { Chlorinated } \\
\text { Polyethylene }\end{array}$ \\
\hline Liner No. & --- & 21 & 17 & 7 & 6 & 16 & 12 \\
\hline Generator No. & $-\cdots$ & 19 & 20 & 21 & 22 & 23 & 24 \\
\hline Thickness, mils & $\begin{array}{l}0 \\
1\end{array}$ & $\begin{array}{c}11-12 \\
11\end{array}$ & $\begin{array}{l}20-21 \\
21\end{array}$ & $\begin{array}{c}61 \sim 65 \\
64\end{array}$ & $\begin{array}{c}32-36 \\
38\end{array}$ & $\begin{array}{c}49-53 \\
51\end{array}$ & $\begin{array}{c}31-32 \\
35\end{array}$ \\
\hline Tensile Strength, psi & $\begin{array}{l}0 \\
1\end{array}$ & $\begin{array}{l}2145 \\
2465\end{array}$ & $\begin{array}{l}2580 \\
2350\end{array}$ & $\begin{array}{l}1435 \\
1395\end{array}$ & $\begin{array}{l}1765 \\
1640\end{array}$ & $\begin{array}{l}1475 \\
1455\end{array}$ & $\begin{array}{l}2270 \\
1810\end{array}$ \\
\hline Elongation at Break, $\mathscr{x}$ & $\begin{array}{l}0 \\
1\end{array}$ & $\begin{array}{l}505 \\
560\end{array}$ & $\begin{array}{l}280 \\
330\end{array}$ & $\begin{array}{l}395 \\
410\end{array}$ & $\begin{array}{l}250 \\
300\end{array}$ & $\begin{array}{l}410 \\
435\end{array}$ & $\begin{array}{l}410 \\
400\end{array}$ \\
\hline Tensile Set, $\%$ & $\begin{array}{l}0 \\
1\end{array}$ & $\begin{array}{l}422 \\
432\end{array}$ & $\begin{array}{l}73 \\
57\end{array}$ & $\begin{array}{l}17 \\
14\end{array}$ & $\begin{array}{l}111 \\
106\end{array}$ & $\begin{array}{l}16 \\
12\end{array}$ & $\begin{array}{l}429 \\
208\end{array}$ \\
\hline $5-200$, (a) psi & $\begin{array}{l}0 \\
1\end{array}$ & $\begin{array}{l}1260 \\
1205\end{array}$ & $\begin{array}{l}1965 \\
1550\end{array}$ & $\begin{array}{l}690 \\
685\end{array}$ & $\begin{array}{l}1520 \\
1245\end{array}$ & $\begin{array}{l}760 \\
740\end{array}$ & $\begin{array}{l}1330 \\
1090\end{array}$ \\
\hline Tear Strength (Die C), ppi & $\begin{array}{l}0 \\
1\end{array}$ & $\begin{array}{l}390 \\
496\end{array}$ & $\begin{array}{l}335 \\
450\end{array}$ & $\begin{array}{l}180 \\
202\end{array}$ & $\begin{array}{l}300 \\
305\end{array}$ & $\begin{array}{l}181 \\
195\end{array}$ & $\begin{array}{l}255 \\
320\end{array}$ \\
\hline Hardness (Duro A $-10 \mathrm{~s}$ ) & $\begin{array}{l}0 \\
1\end{array}$ & $\begin{array}{c}98 \\
---\end{array}$ & $\begin{array}{l}76 \\
64\end{array}$ & $\begin{array}{l}51 \\
50.5\end{array}$ & $\begin{array}{l}79 \\
64\end{array}$ & $\begin{array}{l}54 \\
51.5\end{array}$ & $\begin{array}{l}85 \\
65.5\end{array}$ \\
\hline $\begin{array}{l}\text { Puncture Resistance(b) } \\
\text { force, lb }\end{array}$ & $\begin{array}{l}0 \\
1\end{array}$ & $\begin{array}{l}11.9 \\
14.8\end{array}$ & $\begin{array}{l}25.8 \\
30.1\end{array}$ & $\begin{array}{l}44.8 \\
49.5\end{array}$ & $\begin{array}{l}32.9 \\
57.0\end{array}$ & $\begin{array}{l}39.4 \\
40.1\end{array}$ & $\begin{array}{l}47.0 \\
49.8\end{array}$ \\
\hline Elongation, in. & $\begin{array}{l}0 \\
1\end{array}$ & $\begin{array}{l}0.76 \\
0.80\end{array}$ & $\begin{array}{l}0.69 \\
0.70\end{array}$ & $\begin{array}{l}1.22 \\
1.20\end{array}$ & $\begin{array}{l}0.60 \\
0.88\end{array}$ & $\begin{array}{l}1.44 \\
1.18\end{array}$ & $\begin{array}{l}1.04 \\
0.98\end{array}$ \\
\hline Volatiles at $105^{\circ} \mathrm{C}$ & 1 & 0.02 & 3.55 & 2.02 & 12.76 & 5.54 & 6.84 \\
\hline Seam Strength Peel, ppi & $\begin{array}{l}0 \\
1\end{array}$ & $\begin{array}{l}15.6 \\
10.3(\mathrm{c})\end{array}$ & $\begin{array}{l}40 \\
5.1\end{array}$ & $\begin{array}{l}3.8 \\
2.9\end{array}$ & $\begin{array}{r}30.0 \\
3.4\end{array}$ & $\begin{array}{l}2.5 \\
2.0\end{array}$ & $\begin{array}{r}10.0 \\
5.1\end{array}$ \\
\hline Shear, ppi & $\begin{array}{l}0 \\
1\end{array}$ & $\begin{array}{l}20.2 \\
11.4\end{array}$ & $\begin{array}{l}37.2 \\
25.6\end{array}$ & $\begin{array}{l}30.0 \\
42.0\end{array}$ & $\begin{array}{l}50 \\
40.2\end{array}$ & $\begin{array}{l}14.6 \\
24.3\end{array}$ & $\begin{array}{l}57 \\
35\end{array}$ \\
\hline
\end{tabular}

\footnotetext{
(a) Stress at $200 \%$ elongation.

(b) Rate of penetration of probe $20 \mathrm{in.} / \mathrm{min}$

(c) Seam in the polyethylene liner used in the steel column. Tabs in the liner specimens mounted in base were too shart.
} 
attack by ozone and microbes, and are available in 20- to 60-mil sheets (Du Pont C). However, neoprene is susceptible to damage from acid and strong salt solutions expected in tailings impoundments, exposure to weathering when in contact with earth, and seaming must be performed above $10^{\circ} \mathrm{C}$ (Williams 1978 ; Du Pont A). Radiation resistance of neoprene is comparable to hypalon, but it is still not suitable for this application (Du Pont D).

Plastics

Elasticized Polyolefin $(3110,3111)$

Elasticized polyolefin is a thermoplastic material with good aging characteristics and resists attack by oily solutions, microbes, and solutions from 2 to $13.5 \mathrm{pH}$. Because the material is not vulcanized, field heat-seaming is possible at rates to $360 \mathrm{~m} / \mathrm{h}$. The material is extruded rather than calandered and is available in $6-m \times 61-m \times 20-m i]$ sheets. Because of the extrusion processing, the material is not available with fiber reinforcement, which thus limits the applicability of the material. This liner must not be exposed to hydrocarbons, steep slopes (>33\%) or impoundments where wet/marshy conditions exist. No radiation resistance data is available. Du Pont does not warranty this materia] (Williams 1978; Du Pont B; Du Pont C).

\section{Polyethylene}

Since polyethylene materials do not contain a plasticizer, extrusion-forming processes are required and sheet thickness is limited to $8 \mathrm{~mm}$. Polyethylene has poor resistance to UV exposure, requires an adhesive tape-style seal that is difficult to make, has limited puncture resistance and tends to crack in creases. Any advantages of the material (chemical inertness and radiation resistance) do not overcome the limitations (Stewart 1978; Williams 1978; Du Pont D; Haxo 1976a).

However, polyethylene is available in high- and low-density specifications. High-density polyethylene appears to have excellent durability during conditions expected in impoundment of uranium-mill tailings. Its lack of plasticizers eliminates microbial attack concerns and is resistant to 1) degradation from hydrocarbons thought to be contained in tailings piles, 2) high 
acidity, and 3) ultraviolet radiation. These data make high-density polyethylene well worth considering for testing in the laboratory.

\section{Polyvinyl Chloride}

Polyvinyl chloride (PVC) is a calandered material available in a wide variety of thicknesses, colors, and composition. PVC exhibits good resistance to puncture and microbes, has low permeability $\left(7.3 \times 10^{-13}\right.$ for a $20-\mathrm{mi}_{1}$ sheet), and is chemicaliy stable in the environment expected in the tailings piles. Principal disadvantages of PVC include susceptibility to breakdown from exposure to UV below $355 \mu \mathrm{m}$ resulting in cross-bonding and increased stiffness, migration of plasticizers also resulting in increased stiffness, and moderate garma exposures resulting in a compound that becomes soft and tacky. As with low-density polyethylene, the inherent limitations are serious enough to preciude PVC from serious consideration as a candidate liner material (Savartnick 1969; Stewart 1978; Williams 1978; Du Pont D; Haxo 1976a).

Chlorinated Polyethylene

Chlorinated polyethylene (CPE) is a calandered thermoplastic available from 20 to $45 \mathrm{mil}$ in thickness and with a polyolefin reinforcing sheet. The material is produced by chlorinating high-density polyethylene and can be seamed by adhesive solvent, solvent welding, or heat-sealing techniques. CPE is not susceptible to ozone or ultraviolet radiation, resists hydrocarbons, is unaffected by microbes, and has a permeability of $2\left(10^{-12}\right) \mathrm{cm} / \mathrm{s}$ for a $30-\mathrm{mil}$ sheet. The material, however, is reported to have a 1 imited resistance to acids, requires reinforcement for use on slopes, and is not recommended on slopes of over $2 \mathrm{~m}$ rise to $3 \mathrm{~m}$ horizontal. Susceptibility to acid attack precludes any further consideration of the material. 


\section{CHARACTERIZATION STUDY OF URANIUM-MILL TAILINGS}

The objectives of the Characterization Study of the Liner Evaluation Program are to determine the chemical properties of the tailings at the four priority sites and the physical properties of the soils at the selected permanent repository sites. The chemical contents of the tailings need to be known to determine the conditions the liners need to be subjected to in testing the effectiveness of the liners. The physical properties of the repository soils would indicate indigenous sealing properties and, thus, the necessity of an additional liner.

Samples of tailings have been taken from the Salt Lake City, Durango and Shiprock sites; the Canonsburg site is currently inaccessible. Each of the three sites was sampled at the locations indicated in Figures 2, 3, and 4 with each sample composited over a depth of about $6 \mathrm{ft}$. At the time of sampling, a wide range of textures was noted among locations on a single pile, apparently

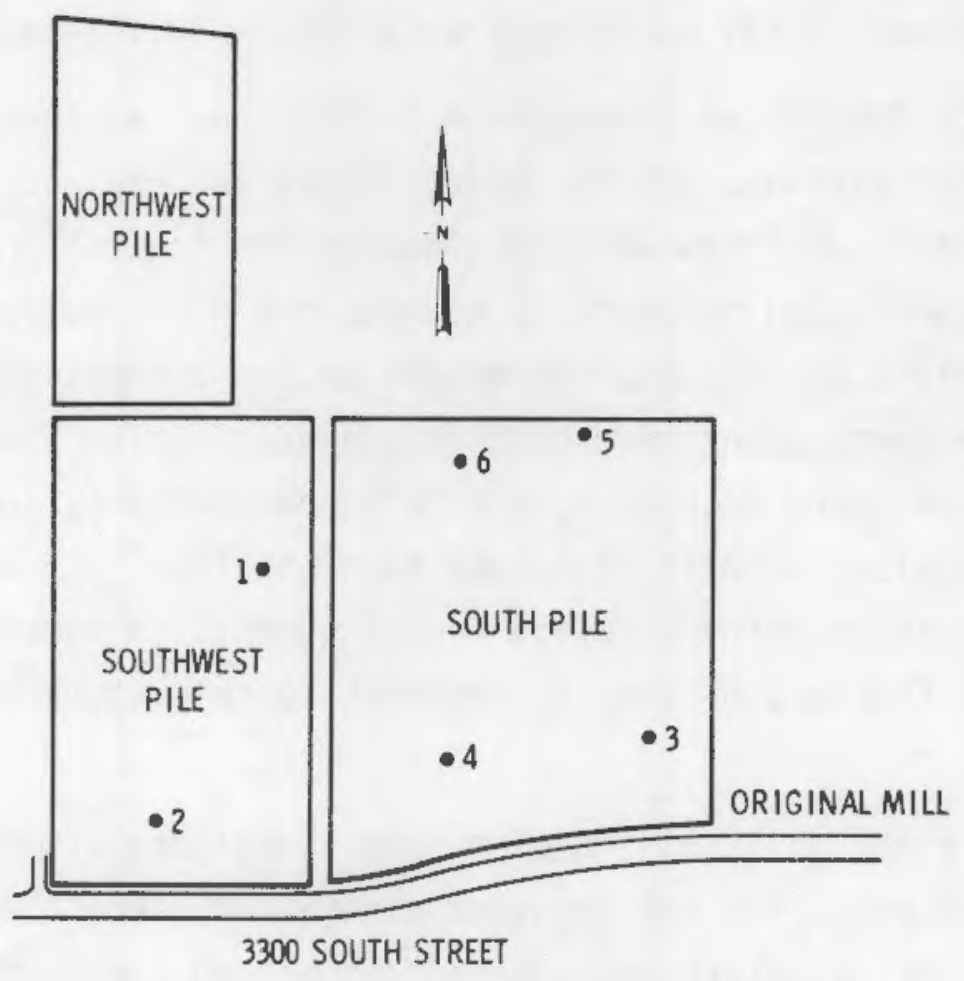

FIGURE 2. Sample Sites on the Salt Lake City Vitro Tailings Pile 


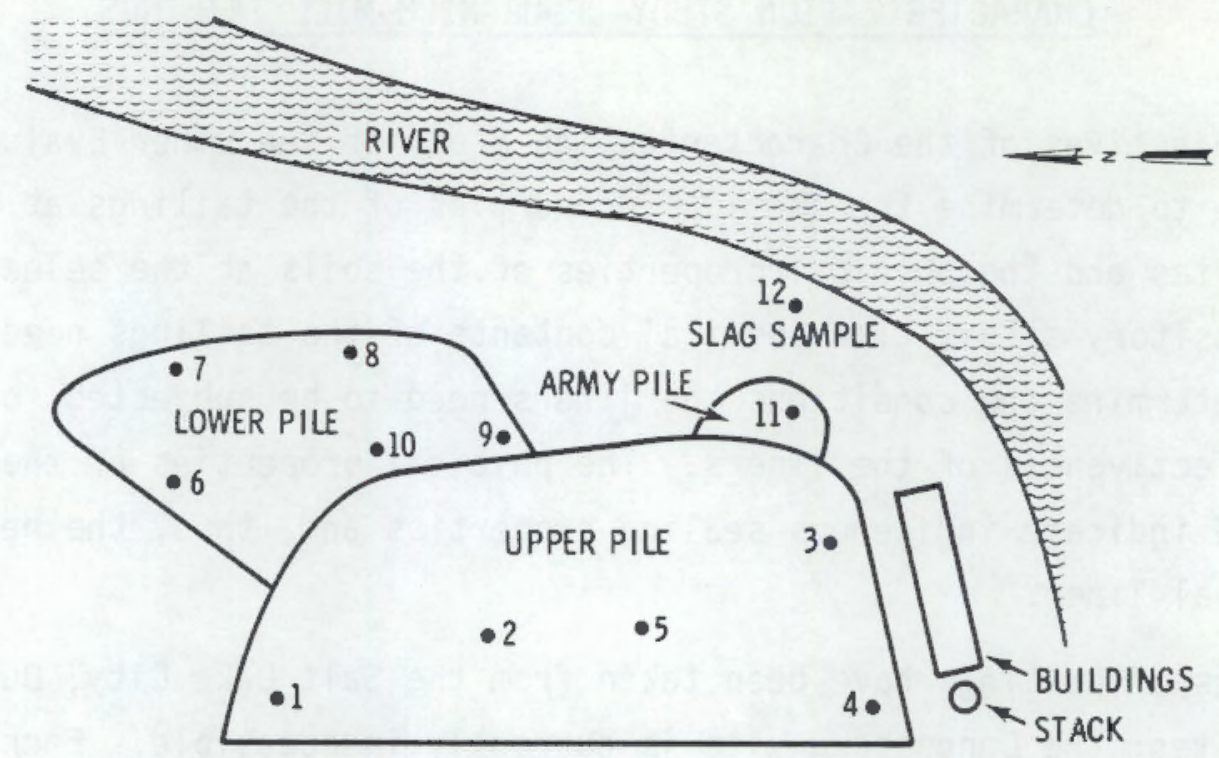

FIGURE 3. Sample Sites on the Durango Tailings Pile

the result of how the slimes and sands settled in the original tailings pond. At Salt Lake City, samples taken for moisture determinations showed that moisture content was positively correlated with increased fineness of texture.

The tailings samples were sealed in buckets and returned to the laboratory to be analyzed for cations, anions, hydrocarbons and radionuclides. Extracts for cation and anion analyses were obtained by shaking tailings with water in a 1:100 wt\% concentration for about $2 \mathrm{~h}$. Cations were analyzed by Inductively Coupled Argon Plasma techniques, the anions by ion chromatography, and the radionuclides by gamma scan. Hydrocarbon analyses, which have only recently been identified as being necessary, are being performed by infrared spectrometry. The analytical results that have been obtained to date are shown in Table 10. While these methods detect and/or quantify a number of elements and ions, only those that are of special interest to this study are shown in the table.

The study of the soils at the permanent repository sites for the four priority tailings piles has not progressed very far since the sites have not been selected. The selection process has progressed furthest at the Salt Lake 


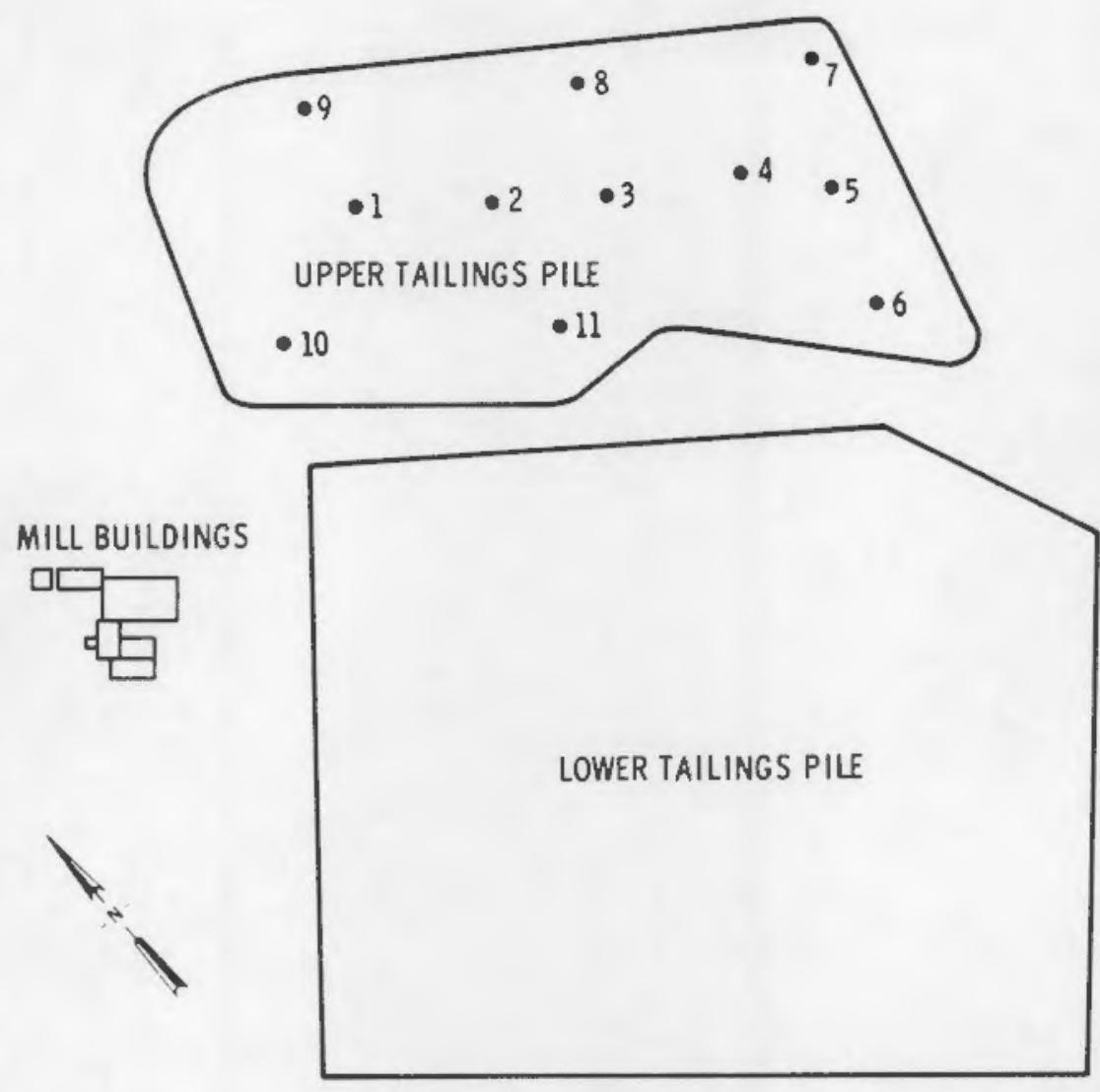

FIGURE 4. Sample Sites on the Shiprock Tailings Pile

City pile where the final choice of a repository has been narrowed to three sites.

Soil samples have been obtained from the three sites, and the soil materials have been tentatively classified as silty clays. Soil surveys in Tooele County indicate that the clays in the area are likely a mixture of montmorillonites and illites. This would tend to point to the conclusion that a liner may not be necessary to prevent leaching from either site. However, when the samples were taken, the soil profiles indicated moisture to a depth of at least $4 \mathrm{ft}$ as shown in Table 11. The sites were sampled on 11 September 1978 . The area had received rain the day before. It is not known whether the water penetrated the soil to the sampling depth as a result of the previous day's rain or whether the soil is so poorly drained that it remains wet. The latter seems most likely. Further analyses on these soils have not been conducted, but 

TABLE 10. Analytical Results From Tailings at Salt Lake, Durango and Shiprock Sites Using 100:1 Leachant-to-Sample Ratio
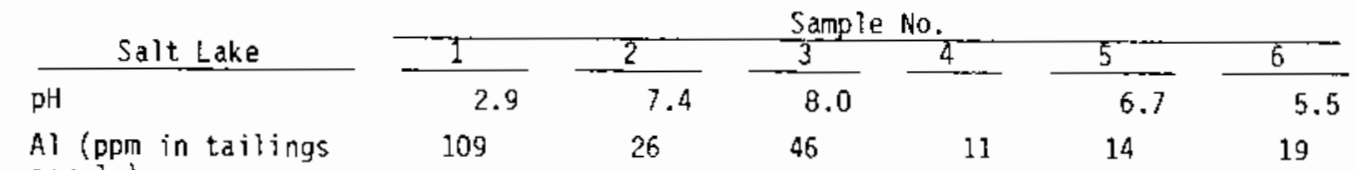

A) (ppm in tailings

$\mathrm{Ca}(\mathrm{ppm})$

$\mathrm{Fe}$ (ppm)

$\mathrm{Mg}(\mathrm{ppm})$

Na (ppm)

Si $(\mathrm{ppm})$

$\mathrm{SO}_{4}(\mathrm{ppm})^{(\mathrm{a})}$

$\mathrm{NO}_{3}(\mathrm{ppm})$

Cl $(\mathrm{ppm})$

$210 \mathrm{~Pb}(\mathrm{dprm} / \mathrm{g})$

${ }^{238} \mathrm{U}$ and ${ }^{234} \mathrm{Th}$

$(\mathrm{dpm} / \mathrm{g})$

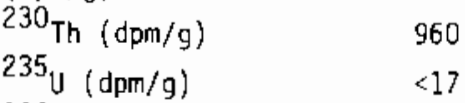

$225 \mathrm{U}(\mathrm{dpm} / \mathrm{g})$

24,200

$14,000 \quad 8,290$

$26,000 \quad 36,200 \quad 25,500$

$\begin{array}{rrrrrr}62 & 88 & 194 & 500 & 2 & 3 \\ & 800 & 230 & 256\end{array}$

$\begin{array}{llllll}162 & 290 & 235 & 1,800 & 1,330 & 660\end{array}$

$\mathrm{Ra}(\mathrm{dpm} / \mathrm{g})$

$\begin{array}{rr}17 & 238 \\ 2,400 & 1,670\end{array}$

$\begin{array}{rr}238 & 305 \\ 1,670 & 1,670\end{array}$

$\begin{array}{lll}566 & 153 & 87\end{array}$

$\begin{array}{lllll}<1 & 8,140 & 2,720 & 2,230\end{array}$

$6.4 \quad 12 \quad 14$
2.430

, 430

90

1,370

$\begin{array}{rrr}<1 & 383 & 310 \\ 1,333 & 79 & 15\end{array}$

1,970

$960-620 \quad 460$

$<17 \quad 10$

1,240

29

\begin{tabular}{|c|c|c|c|c|c|c|c|c|c|c|}
\hline \multirow[b]{2}{*}{ Durango } & \multicolumn{10}{|c|}{ Sample No. } \\
\hline & 1 & 2 & 3 & 4 & $-\frac{1}{6}$ & 7 & 8 & 9 & 10 & 11 \\
\hline pH & 9.9 & 10.0 & 9.8 & 10.0 & 9.4 & 9.5 & 7.1 & 7.5 & 9.6 & 7.0 \\
\hline $\begin{array}{l}\text { Al (ppm in taflings } \\
\text { sample) }\end{array}$ & 32 & 11 & 11 & 17 & 63 & 162 & 6 & 16 & 11 & $<3$ \\
\hline Ca $(p p m)$ & 1,170 & 1,140 & 800 & 1,060 & 375 & 989 & 2,170 & 600 & 860 & 174 \\
\hline $\mathrm{Fe}(\mathrm{ppm})$ & 4.1 & --- & 2 & 1 & 23 & 35 & 4 & 6 & -- & 2 \\
\hline $\mathrm{Mg}(\mathrm{ppm})$ & 132 & 100 & 18 & 86 & 37 & 68 &.-- & 11 & 136 & -- \\
\hline $\mathrm{Na}(p \mathrm{pm})$ & 230 & 110 & 116 & 377 & 75 & 112 & 32 & 45 & 368 & 32 \\
\hline Si (ppm) & 106 & 60 & 130 & 73 & 343 & 500 & 90 & 100 & 198 & 38 \\
\hline $\begin{array}{l}\mathrm{CO}_{3} \text { (ppm-assumed } \\
\text { from inarganic car- } \\
\text { bon and lysis) }\end{array}$ & 3,500 & 3,060 & 1,600 & 2,500 & 1,590 & 2,000 & 280 & 365 & 3,100 & 280 \\
\hline $50 \mathrm{~A}$ & low & low & low & low & --- & -- & $\cdots$ & -- & --- & --- \\
\hline $210 \mathrm{~Pb}$ & & 1,500 & & & 1,530 & & & & & 995 \\
\hline${ }^{238} \mathrm{U}$ and ${ }^{234} \mathrm{Th}$ & & 575 & & & 275 & & & & & 154 \\
\hline${ }^{230}$ Th & & 2,840 & & & 2,035 & & & & & 1,520 \\
\hline $235_{u}$ & & 27 & & & $<14$ & & & & & 12 \\
\hline${ }^{226} \mathrm{Ra}$ & & 2,300 & & & 1,940 & & & & & 1,360 \\
\hline
\end{tabular}

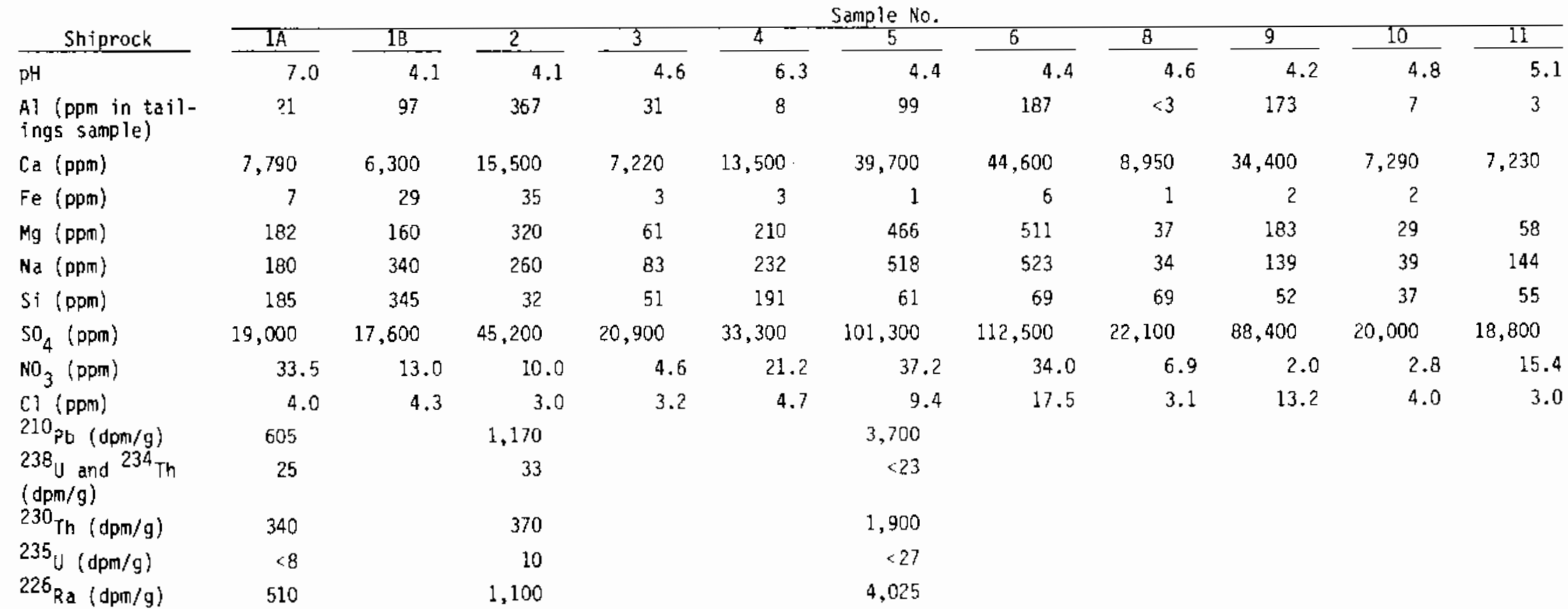

(a) Performed with 1:1 leachant to sample ratio. Concentration limited by solubility product. 

TABLE 11. Moisture Profiles at Great Salt Lake Desert Sites

\begin{tabular}{|c|c|c|}
\hline \multirow[b]{2}{*}{ Depth, in. } & \multicolumn{2}{|c|}{ Moisture \% } \\
\hline & Delle & Knolls \\
\hline $0-6$ & 33 & 19 \\
\hline $6-12$ & 54 & 21 \\
\hline $12-18$ & 59 & 25 \\
\hline $18-24$ & 48 & 46 \\
\hline $24-30$ & 39 & 29 \\
\hline $30-36$ & 21 & 29 \\
\hline $36-48$ & - & 34 \\
\hline
\end{tabular}

identification of the clays by x-ray diffraction, permeability and coefficient of linear extensibility tests are being considered.

Additional work that may be needed at these Utah sites includes regional hydrologic surveys and compressibility of the soils from the weight of the tailings. Both of these are critical to the long-term integrity of liners. 


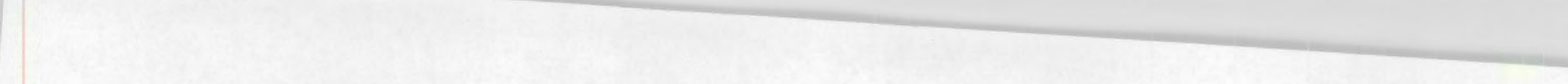




\section{FIELD STUDIES}

Two liners, a catalytic airblown asphalt membrane, and a bentonite, sand, and gravel mixture, were installed in a trench at the Grand Junction mill tailings site for field evaluation. These materials, chosen before the liner selection study was completed, will also be subjected to accelerated laboratory tests for a control comparison of field and laboratory results.

\section{SITE PREPARATION}

The trench in which the liners were installed was constructed to simulate the bottom of a tailings repository. It measured $76 \mathrm{~m}$ long by $12 \mathrm{~m}$ wide and had a maximum depth of $0.8 \mathrm{~m}$. The trench, depicted in Figure 5 , was

\section{POINT OF REFERENCE RELATIVE ELIVATION}

$\begin{array}{ll}A & 0 \mathrm{~m} \\ B & +0.05 \mathrm{~m} \\ C & -0.28 \mathrm{~m} \\ E & -0.28 \mathrm{~m} \\ F & -0.41 \mathrm{~m} \\ H & -0.30 \mathrm{~m} \\ 1 & -0.28 \mathrm{~m} \\ J & -0.30 \mathrm{~m}\end{array}$ AVERAGE $=-0.22 \mathrm{~m}$

\section{TRENCH BOTTOM}

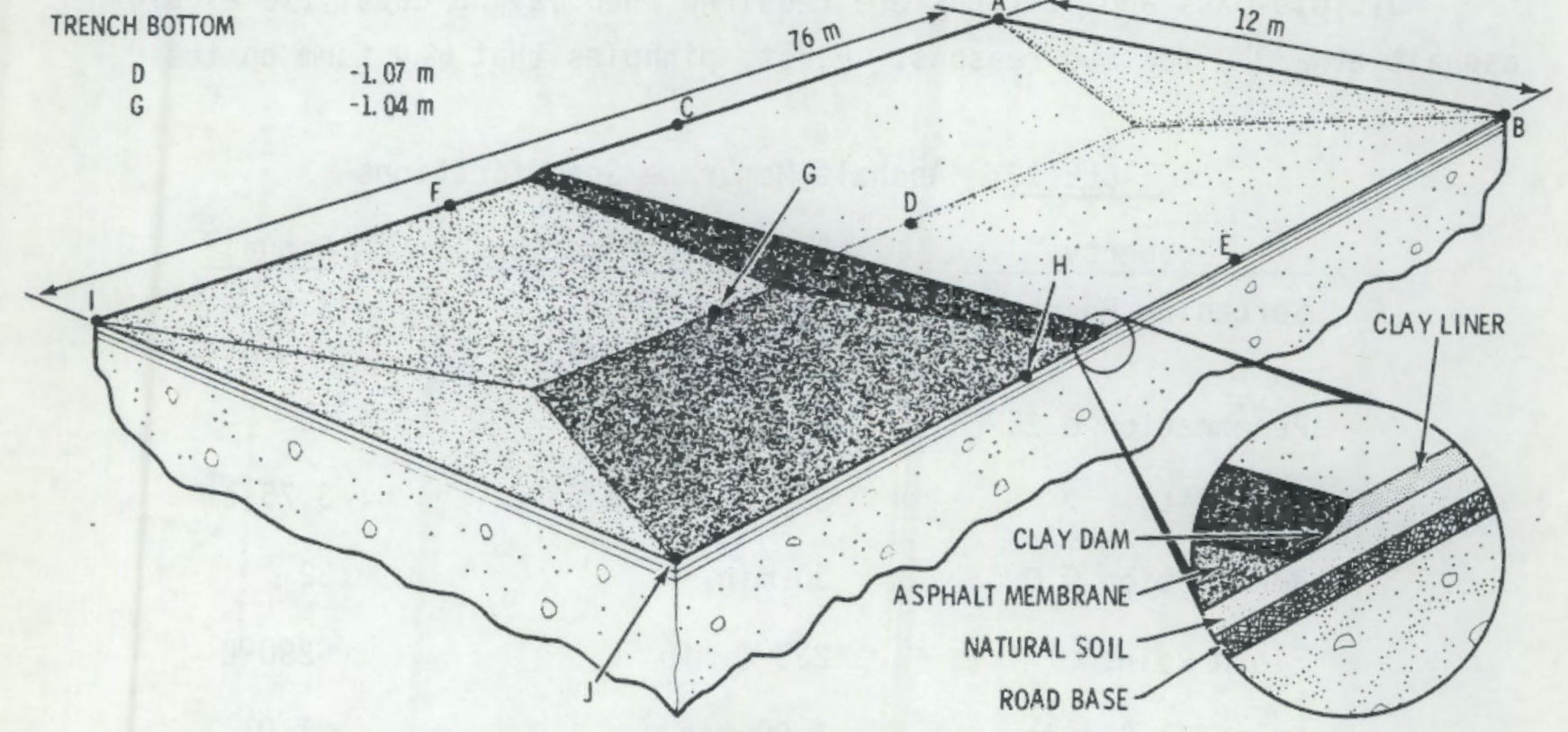

FIGURE 5. Trench Oimensions for Liner Field Test 
stabilized with a roadbase gravel and covered with a $15-\mathrm{cm}$ natural soil layer. At the west end of the trench where the asphalt membrane was to be applied, the soil was dampened and rolled smooth to avoid ridges larger that the membrane thickness. The roadbase at the east end of the trench where the clay liner was laid contained larger-size rocks up to $3.8 \mathrm{~cm}$ to act as an upward moisture barrier. In this way, concentrations of radionuclides and chemical contaminants in the soil layer can be attributed solely to moisture transport downwards through the liner. Both the gravel base and the soil layer were compacted with a roller before placement of the clay liner.

\section{ASPHALT MEMBRANE INSTALLATION}

Catalytic airblown asphalt was chosen as the processed material liner for the field studies because of its ability to retain its tough and flexible qualities over long periods of time (The Asphalt Institute 1976). Other materials, such as rubberized asphalts and asphalt emulsion admixtures, are proving their worth in hydraulics but do not have the industrial experience as does the airblown asphalt. Table 12 lists the ASTM specifications of the asphalt laid in the Grand Junction field test.

Multiple-pass applications are required when laying catalytic airblown asphalt at $230^{\circ} \mathrm{C}$ for two reasons. First, pinholes that may form on the

\section{TABLE 12. Asphait Membrane Specifications}

\begin{tabular}{|c|c|c|}
\hline Property & ASTM Specifications & Actual \\
\hline Softening Point & $\begin{array}{l}82^{\circ} \mathrm{C} \text { to } 93^{\circ} \mathrm{C} \\
\left(180 \text { to } 200^{\circ} \mathrm{F}\right)\end{array}$ & $85^{\circ} \mathrm{C}$ \\
\hline Penetration $25^{\circ} \mathrm{C}$ & 50 to 60 & 53 \\
\hline Ductility & $3.5 \mathrm{~cm} / \mathrm{min} \odot 25^{\circ} \mathrm{C}$ & $3.75 \mathrm{~cm}$ \\
\hline Penetration $\bigcirc 0^{\circ} \mathrm{C}$ & $30 \mathrm{~min}$ & 32 \\
\hline Flash Point & $230^{\circ} \mathrm{C} \min$ & $\sim 290^{\circ} \mathrm{C}$ \\
\hline Specific Gravity & $1.00 \mathrm{~min}$ & 21.01 \\
\hline
\end{tabular}


first pass from percolation of water vapor through the membrane before it cools can be filled on succeeding applications (The Asphalt Institute 1976). Second, spraying in different directions at slightly opposed angles will coat both sides of any irregularities of the prepared surface. The recommended thickness for ponds and canal linings is $6 \mathrm{~mm}$ sprayed at a rate of $7 \mathrm{~L} / \mathrm{m}^{2}$.

These precautions and application thicknesses were observed during installation of the asphalt membrane in the trench. After priming the surface with $1100 \mathrm{~L}$ of cationic slow-set emulsion, the asphalt membrane was applied in multiple layers with a hand-held gun from a variety of positions as shown in Figure 6. A total of $5500 \mathrm{~L}$ of asphalt was applied at an application rate of $11.9 \mathrm{~L} / \mathrm{m}^{2}$, which is $70 \%$ higher than the recommended minimum. The excess, added to ensure that pinholes and irregularities were covered, created some sloughing on the sloped walls, so that the membrane thickness at the top of the trench was the recommended minimum of $7 \mathrm{~mm}$. A clay dam separates the clay and asphalt liners for independent assessments of material performances. Figure 7 shows the completed asphalt-lined trench before tailings were reintroduced and saturated with water.

\section{CLAY LINER INSTALLATION}

The clay liner consists of a mixture of sodium bentonite, gravel and sand in a ratio of $770 \mathrm{~kg}$ clay: $1640 \mathrm{~kg}$ gravel: $4250 \mathrm{~kg}$ sand. Following compaction of the underlying soil, this mixture was spread with an asphalt-laying machine in a layer $15 \mathrm{~cm}$ thick. This layer was compacted with a rubber-tired tractor since the mixture when wet is too sticky for a roller. Tailings were replaced to $f i l l$ the trench to grade and then sprayed with water to make a standing water table above the liner. A polyethylene film was laid over the surface to prevent loss of water by evaporation so that any water loss can be credited to percolation through the liner.

\section{MONITORING OF CONDITIONS}

Adequate instrumentation was installed above and below the liners for monthly monitoring of exposure temperature, moisture migration, radionuclide 


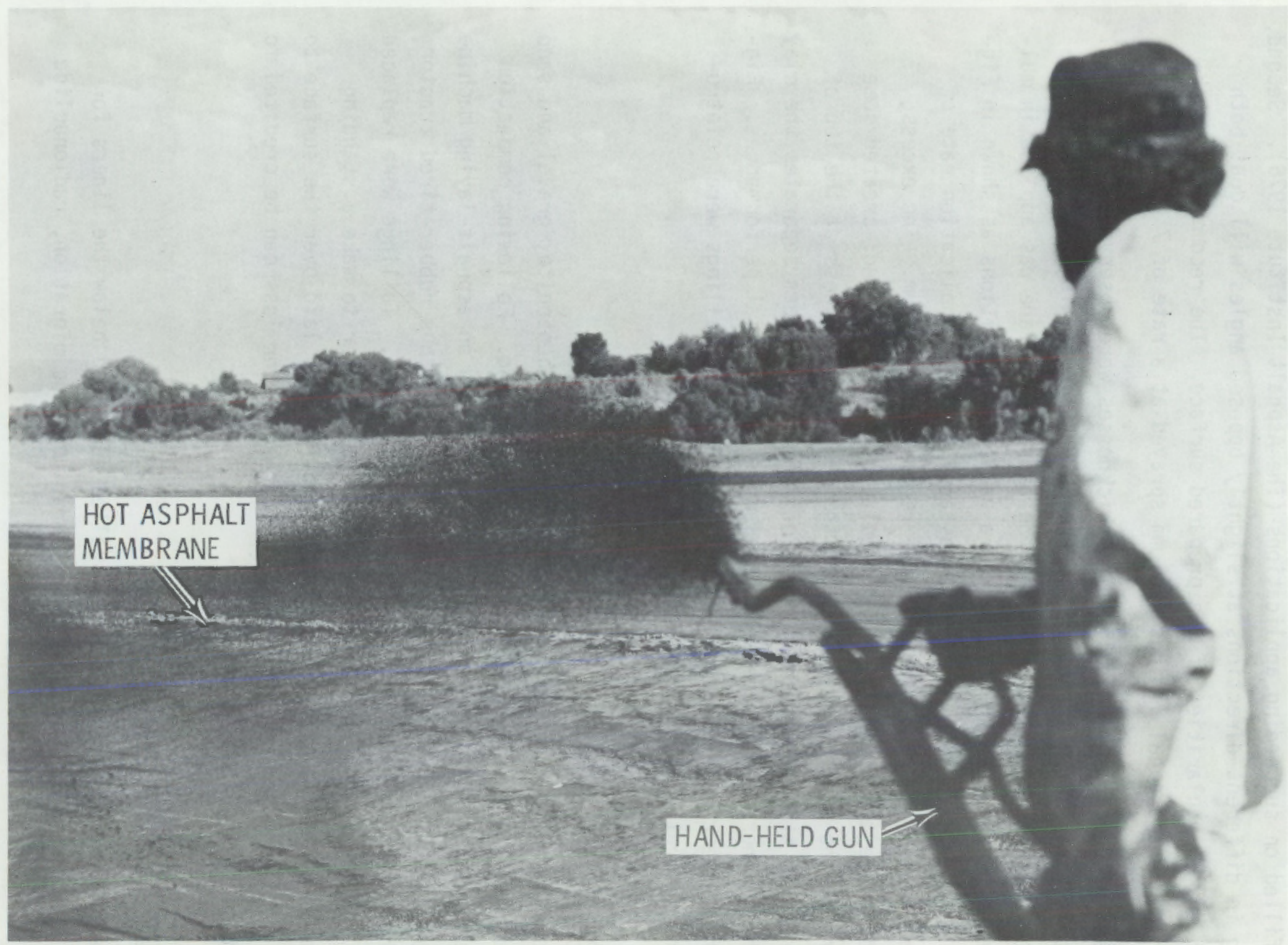

FIGURE 6. Application of Asphalt Membrane 


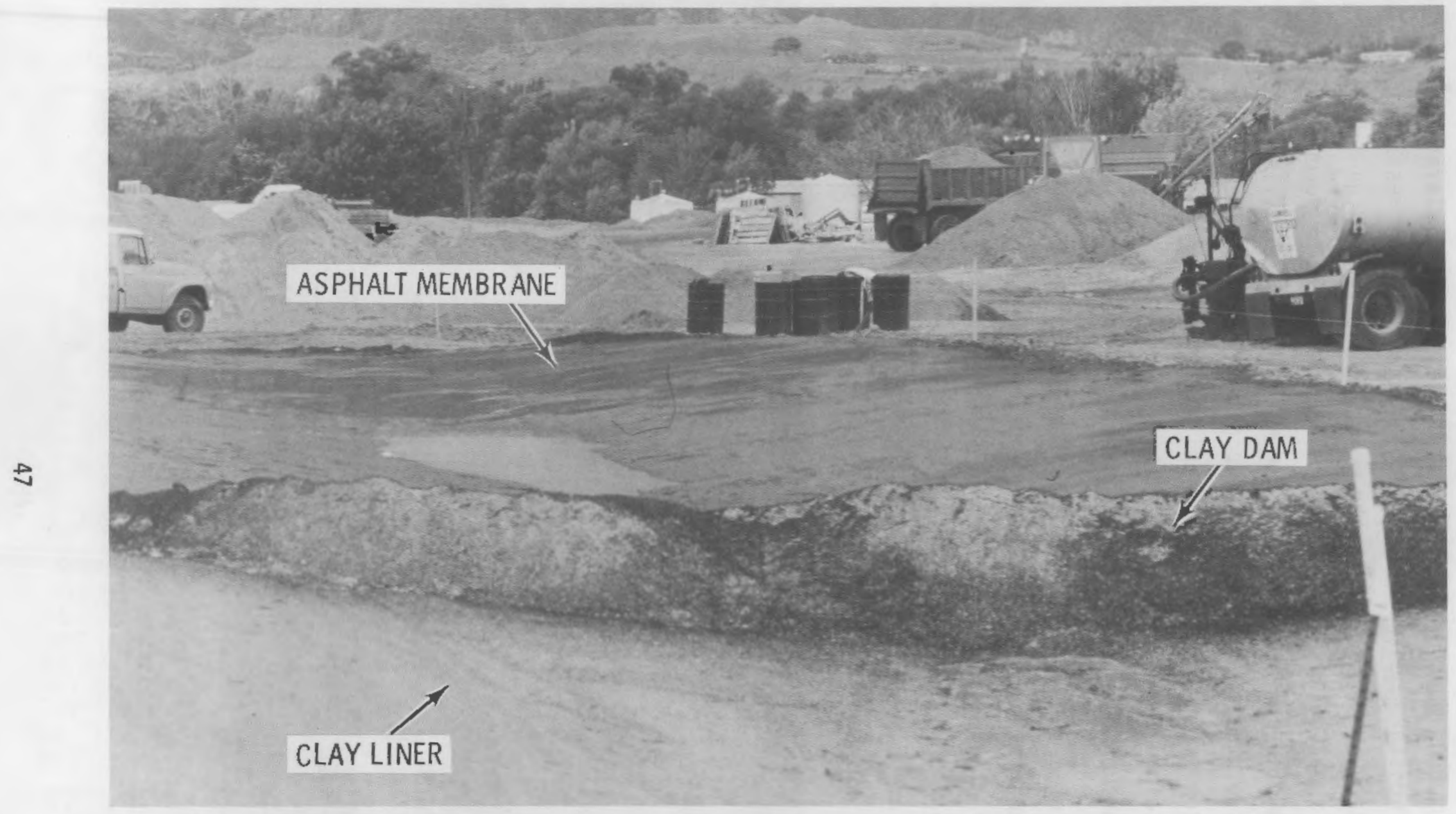

FIGURE 7. Trench After Clay and Asphalt Liners Installed 
and chemical migration through the liner, and hydrostatic pressure above the liner. Four bouyoucus moisture blocks installed in the soil layer beneath the liners indicate moisture content as a function of electrical resistivity. Two moisture extraction cups, shown with the moisture blocks in Figure 8 , were also installed below the clay liner. The cups are constructed of porous ceramic so that moisture samples can be drawn from the soil into the cup via a vacuum force. Analysis of these samples will help determine ion-exchange capabilities of the bentonite. Moisture samples and standing-water depth above the liner can be obtained through four piezometers. Soil thermometers have also been installed around the liners to measure temperature conditions.

At the end of a 6-mo monitoring task, samples of the liners will be examined for integrity such as resistance to chemical attack (i.e., calcium ion exchange for clays or low pH corrosion for the asphalt), cracking, oxidative penetration, etc. The tailings will be resaturated at that time for further monitoring and exposure to field conditions.

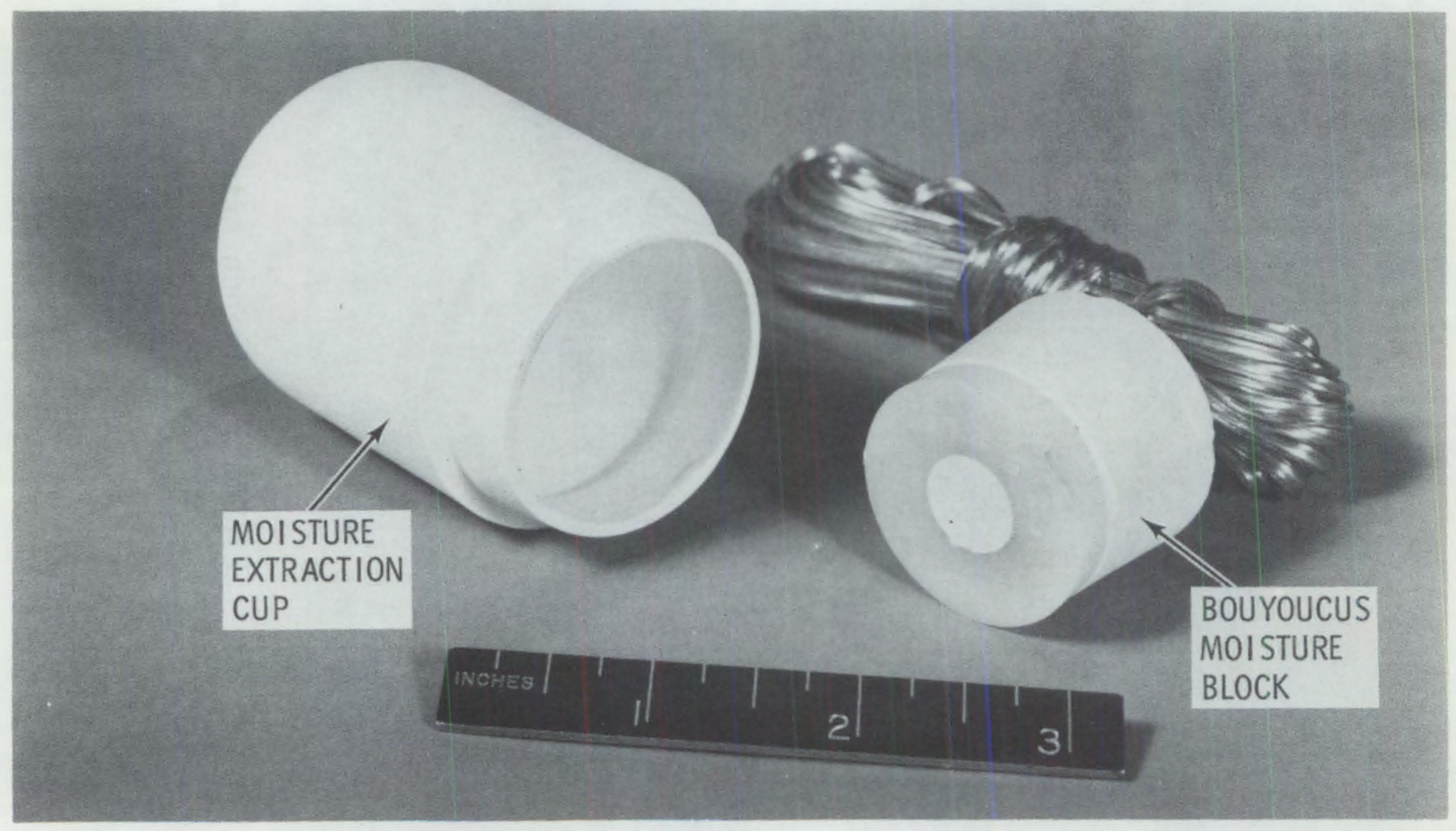

FIGURE 8. Moisture Extraction Cups and Moisture Blocks 


\section{CONCLUSIONS AND FUTURE OBJECTIVES}

As indicated earlier, the liner selection study was conducted to identify eight prospective lining materials for laboratory testing under controlled, accelerated conditions. The preliminary evaluation has identified the following materials:

- natural soil amended with Volclay Saline Seal 100;

- local clay in conjunction with an asphalt emulsion cover for radon suppression;

- local clay in conjunction with a radon multibarrier cover;

- rubberized asphalt membrane;

- hydraulic asphalt conerete;

- chlorosulphonated polyethylene (hypalon) or high-density polyethylene (>30 mils);

- bentonite, sand, and gravel mixture;

- catalytic airblown asphalt.

These materials will be exposed in $30-$ to $60-\mathrm{cm}$-dia test units that are simulations of actual tailings piles. The locally available clays will be tested in conjunction with radon suppression covers to determine their influence on moisture migration. The rubberized and hydraulic asphalts are the two most viable candidates of the asphalt materials. Their common use in pond and canal liners, and the natural properties offer great expectations for long-term durability in uranium-mill tailings impoundments. High-density polyethylene or hypalon were chosen as the top two synthetic liner materials. Laboratory screening tests will be performed to decide which of the two materials undergoes further testing under accelerated conditions. The final two materials are included to correlate the laboratory test results with data collected in the field.

The eight materials will be exposed to conditions representative of $1000 \mathrm{yr}$. After a 3-mo test, the materials will be examined. The most 
suitable liner or composite of materials will then be installed in the field for exposure of $2 \mathrm{yr}$. Ongoing laboratory research will evaluate newly identified materials or composites that appear promising under improved testing techniques. 


\section{REFERENCES}

Anonymous. 1969a. Report of Investigation of Chemical Grouts for Rock Bonding Report I. Report AD 692854, National Technical Information Service, Springfield, Virginia.

Anonymous. 1969b. Report of Investigation of Chemical Grouts for Rock Bonding, Report II. Report AD 692855, National Technical Information Service, Springfield, Virginia.

The Asphalt Institute. 1976. Asphalt in Hydraulics. Manual Series No. 12, College Park, Maryland.

Aul, G. N. and J. Cervik. 1976. Grouting of Horizontal Drainage Holes in Coalbeds. Report of Investigations B375, U.S. Department of the Interior, Bureau of Mines, Washington, DC. Report PB 80-110315, National Technical Information Service, Springfield, Virginia.

Blodgett, R. B. and R. G. Fisher. 1969. Insulations and Jackets for Control and Power Cable in Thermal Reactor Nuclear Generating Stations. Okonite Company, Passaic, New Jersey, Institute of Electric and Electronic Engineers.

Clark, D. A. et al. 1974. An Evaluation of Tailings Pond Sealants. EPA660/2-74-065. U.S. Environmental Protection Agency, National Environmental Research Center, Office of Research and Development Corvalis, Oregon. Report PB 235929, National Technical Information Service, Springfield, Virginia.

Dunning, R. L. 1975. "Rubber in Asphalt Emulsion Systems and Their Rheological Behavior." Paper presented at the Second Annual Meeting of the Asphait Emulsion Manuf acturers Association, March 5, 1975, San Diego, California.

Edwald, G. W. 1973. "Stretching the Lifespan of Synthetic Pond-Linings." Chemical Engineering. October 1, 1973:67-70.

E. I. Du Pont de Nemours and Co. A. "Engineering Guide to the Du Pont Elastomers." Technical Bulletin, E-26276, E.I. Du Pont de Nemours and Co., Inc., Elastomer Chemicals Department, Wilmington, Delaware.

E. I. Du Pont de Nemours and Co. B. "Excerpts from a Du Pont Seminar on Flexible Pond and Reservoir Liners and Covers." E. I. Du Pont de Nemours and Co., Inc., Elastomer Chemicals Department, Wilmington, Delaware.

E. I. Ou Pont de Nemours and Co. C. "Flexible Membranes for Pond and Reservoir Liners and Covers." Technical Bulletin, E-23335, E. I. Du Pont de Nemours and $\mathrm{Co}$. . Inc., Elastomer Chemicals Department, Wilmington, Delaware.

E. I. Du Pont de Nemours and Co. D. "Radiation Resistance or Elastomers and Plastics." E. I. du Pont de Nemours and Co., Inc., Elastomer Chemicals Department, Wilmington, Delaware. 
Frobel, R. K. et al. 1977. Development of a Low-Cost Asphalt-Rubber Membrane for Water Harvesting Catchments and Reservoir Seepage Control. University of Arizona, Tucson, Arizona. Report PB 268779, National Technical Information Service, Springfield, Virginia.

Fuller, W. H. 1978. Investigation of Landfill Leachate Pollutant Attenuation by Soils. EPA-600/2-78/158. U.S. EPA MunicipaT Environmental Research Laboratory, Cincinnati, Ohio.

Gee, G. W., A. C. Campbell, D. R. Sherwood, R. G. Strickert and S. J. Phillips. 1980. Interaction of Uranium Mill Tailings Leachate with Soils and Clay Liners. NUREG/CR-1494, PNL-3381, U.S. Nuclear Regulatory Commission, Washington DC.

Griffin, R. A. and N. F. Shimp. 1978. Attenuation of Pollutants in Municipal Landfill Leachate by Clay Minerals. EPA-600/2-78-157. U.S. EPA Municipa? Environmental Research Laboratory, Cincinnati, Ohio.

Gulick, C. W., Jr. et al. 1980. Borehole Plugging Materials Development Program, Report II. SAND-79-1514, Sandia Laboratories, Albuquerque, New Mexico.

Haxo, H. E., Jr. 1976a. "Assessing Synthetic and Admixed Materials for Lining Landfi115." In Gas and Leachate from Landfills, Formation, Collection and Treatment, eds. E. J. Genetel7i and J. Cirel10, pp. 130-158. Report EPA 600/ 9-76-004, U.S. Environmental Protection Agency, Solid and Hazardous Waste Research Division, Municipal Environmental Research Laboratory, Office of Research and Development, Cincinnati, Ohio. Report PB 251161, National Technical Information Service, Springfield, Virginia.

Haxo, H. E., Jr. 1976b. "Evaluation of Selected Liners When Exposed to Hazardous Wastes." In Residual Management by Land Disposal. Proceedings of the Hazardous Waste Research Symposium, ed. W. N. FuTler, pp. 102-111. Report EPA 600/9-76-015, U.S. Environmental Protection Agency, Solid and Hazardous Waste Research Division, Municipal Environmental Research Laboratory, Office of Research and Development, Cincinnati, Ohio. Report PB 256768, National Technical Information Service, Springfield, Virginia.

Haxo, H. E., Jr. and R. M. White. 1976a. Evaluation of Liner Materials Exposed to Leachate. Matrecon, Inc., OakTand, California. Report PB 259913, National Technical Information Service, Springfield, Virginia.

Haxo, H. E., Jr., and R. M. White. 1976b. Evaluation of Liner Materials Exposed to Leachate, Second Interim Report. EPA-600/2-76-255, National Technical Information Service, Springfield, Virginia.

Haxo, H. E., Jr. et a1. 1977. Liner Materials Exposed to Hazardous and Toxic Sludges. Matrecon, Inc., Oakland, California, Report Number PB 271013, National Technical Information Service, Springfield, Virginia. 
Haxo, H. E., Jr. et al. 1979. Liner Materials Exposed to Municipal Solid Waste Leachate. Matrecon, Inc., Oakland, California. Report PB 299336, National Technical Information Service, Springfield, Virginia.

Hickey, K. B. 1969. Concrete and Epoxy Materials Compared; Load Properties, Durability, and Volume Change. Report C-1313, U.S. Department of the Interior, Bureau of Reclamation, Denver, Colorado. Report PB 183361, National Technical Information Service, Springfield, Virginia.

Hickle, R. 0. 1976. "Impermeable Asphalt Concrete Pond Liner." Civil Engineering. August 1976:56-59.

Hoff, G. C. et a1. 1977. Identification of Candidate Zero Maintenance Paving Materials, Volume 2. U.S. Army Engineer Waterways Experiment Station, Concrete Laboratory, Vicksburg, Mississippi. Report AD A053794, National Technical Information Service, Springfield, Virginia.

Hughes, J. 1974. "Use of Wyoming Bentonite as a Soil Sealant for the Impoundment of Highly Contaminated Industrial Wastes." 29th Annual Industrial Waste Conference. Purdue University, West Lafayette, Indiana.

Lubina, R. H. et al. 1979. "Design and Construction of the Lining System for the Cotter Tailings Impoundment." In Symposium on Uranium Mill Tailings Management, 13-26, Fort Collins, Colorado, November 19-20, 1979. Colorado State University, Civil Engineering Department, Geotechnical Engineering Program, Fort Collins, Colorado.

Mattia, R. F. and D. R. Luh. 1971. "Radiation Resistance of EPDM, Polychloroprene, and Chlorosulfonated Polyethylene." Presented at the 1971 Tri-State Regional Meeting of the Massachusetts, Connecticut, and Rhode Island Rubber Groups, May 13, 1971, Auburn, Masschusetts.

Middlebrooks, E. J. et al. 1978. Waste Water Stabilization Pond Linings. Special Report 78-28, Department of the Army, Cold Regions Research and Engineering Laboratory, Corps of Engineers, Hanover, New Hampshire, Report Number AD A0629903, National Technical Information Service, Springfield, Virginia.

Rollins, M. B. and A. S. Dylla. 1970. "Bentonite Sealing Methods Compared in the Field." Journal of Irrigation and Drainage Division, ASCE. 96(IR2):193203.

Savartnick, H. A. 1969. Polyvinyl Chloride. Robert E. Krieger Publishing Co., Huntington, New York.

Shultz, D. W. and M. P. Miklas, Jr. 1980. "Assessment of Liner Installation Procedures." In: Disposal of Hazardous Wastes. D. Shultz, ed. U.S. Environmental Protection Agency, Office of Research and Development, Municipal Environmental Research Laboratory Report EPA 600/9-80-010, Cincinnati, Ohio. Report PB 80 175086, National Technical Information Service, Springfield, Virginia. 
Stewart, W. S. 1978. State-of-the-Art Study of Land Impoundment Techniques. Report EPA 600/2-78-196, U.S. Environmental Protection Agency, Municipal Environmental Research Laboratory, Office of Research and Development, Cincinnati, Ohio. Report PB 291881, National Technical Information Service, Springfield, Virginia.

Tyson, S. S. 1978. Internally Sealed Concrete for Bridge Deck Protection. Report PB 287803, National Technical Information Service, Springfield, Virginia.

U.S. Department of Energy (DOE). 1980. National Plan for Radioactive Waste Management. Working Draft 2, Washington DC.

U.S. Nuclear Regulatory Commission (NRC). 1979. Draft Generic Impact Statement on Uranium Milling. NUREG-0511, 2 volumes, Washington, DC.

U.S Nuclear Regulatory Comission (NRC). 1980. Final Environmental Statement Related to Western Nuclear, Inc. NUREG-0639, Nuclear Regulatory Commission, Washington $D C$.

Williams, R. E. 1978. "Control and Prevention of Seepage from Uranium Mill Waste Disposal Facilities." In: Proceedings of the Nuclear Energy Agency Seminar on Management, Stabilization and Environmental Impact of Uranium Mill Tailings, July 1978, Albuquerque, New Mexico.

Zobell and Molecke. 1978. Survey of Microbial Degradation of Asphalts With Notes on Relationship to Nuclear Waste Management. SAND 78-1371, Sandia Laboratories, Albuquerque, New Mexico. 


\section{DISTRIBUTIDN}

No. of

Copies

\section{OFFSITE}

A. A. Churm

DOE Chicago Patent Group 9800 South Cass Avenue

Argonne, IL 60439

27 DOE Technical Information Center

R. E. Cunningham

Office of Nuclear Safety

Materials and Safeguards

Room 562

Nuclear Regulatory Conmission

7915 Eastern Avenue

Silver Springs, MD 20910

Waste Management Research Branch Division of Safeguards

Fuel Cycle and Environmenta] Research

Nuclear Regulatory Commission Washington, DC 20545

P. E. Leader

New Uranium Mill Licensing Section

Nuclear Regulatory Commission Washington, DC 20545

H. J. Miller

New Uranium Mil1 Licensing Section

Nuclear Regulatory Commission Washington, DC 20545

W. E. Mott

DOE Division of Environmental Control Technology

Washington, DC 20545
No. of

Copies

K. Baker

Remedial Actions Program

Office of Nuclear Waste Management

Department of Energy

NE-301, GTN

Washington, DC 20545

E. Delaney

Remedial Actions Program

Office of Nuclear Waste Management

Department of Energy

NE-301, GTN

Washington, DC 20545

D. H. Groelsema

Remedial Actions Program

Office of Nuclear Waste Management

Department of Energy

NE-301, GTN

Washington, DC 20545

A. Kluk

Remedial Actions Program

Office of Nuclear Waste

Management

Department of Energy

NE-301, GTN

Washington, OC 20545

S. Meyers/R. Romatowski

Office of Nuclear Waste Management

Department of Energy

NE-30, GTN

Washington, DC 20545

G. Oertel

Office of Nuclear Waste

Management

Department of Energy

NE-320, GTN

Washington, DC 20545 
No. of

Copies

S. A. Mann

DOE Chicago Operations and Region Office

Argonne, IL 60439

J. 0. Neff

DOE Columbus Program Office

$505 \mathrm{King}$ Avenue

Columbus, $\mathrm{OH} 43201$

J. P. Hamric

DOE Idaho Operations Office

505 King Avenue

Idaho Falls, ID 83401

2 J. B. Whitsett

DOE Idaho Operations Office

505 King Avenue

Idaho Falls, ID 83401

S. W. Ahrends

DOE Oak Ridge Operations Office

P. O. BOX E

Oak Ridge, TN 37380

L. Keller

DOE Oak Ridge Operations office

P. O. Box E

Dak Ridge, TN 37380

D. E. Large

DOE Oak Ridge Operations Office

P. O. Box E

Oak Ridge, TN 37380

T. B. Hindman

DOE Savannah River Operations Office

P. 0. Box A

Aiken, SC 29801

R. P. Whitfield

DOE Savannah River Operations Office

P. 0. Box A

Aiken, SC 29801
No. of

Copies

W. B. Wilson

DOE Savannah River Operations Office

P. 0. Box A

Aiken, SC 29801

R. H. Campbell

DOE Albuquerque Operations Office

P. 0. Box 5400

Albuquerque, NM 87185

R. Y. Lowrey

DOE Albuquerque Operations Office

P. 0. Box 5400

Albuquerque, NM 87185

M. L. Matthews

DOE Albuquerque Operations Off ice

P. 0. Box 5400

Albuquerque, NM 87185

A. L. Taboas

DOE Albuquerque Operations Office

P. O. Box 5400

Albuquerque, NM 87185

S. G. Harbinson

DOE San Francisco Operations Office

1333 Broadway

Oak1 and, CA 94612

S. Lichtman

Criteria \& Standards Division

Office of Radiation Programs

Environmental Protection Agency

Washington, DC 20460

Environmental Protection Agency

Technological Assessment

Division

(AW-559)

Office of Radiation Programs

Washington, DC 20460 
No. of

Copies

3. G. Theme lis, Director

Engineering \& Safety Division

DOE Grand Junction Office

P. 0. Box 2567

Grand Junction, CO 81501

Robert Williams

Electric Power Research

Institute

3412 Hillview Avenue

Paio Alto, CA 94304

4 T. Gerusky, Director

Bureau of Radiation Protection P. 0. Box 2063

Harrisburg, PA 17120

4 Edgar D. Bailey

P. E., Administrator

Radiation Control Branch

Texas Department of Health

1100 W. 49th Street

Austin, TX 78756

4 A. J. Hazle, Director

Radiation \& Hazardous Wastes Division

Colorado Department of Health

4210 East 11th Avenue

Denver, CO 80220

4 Ted Wolfe, Environmental Manager Radiation Department

P. 0. Box 968

Santa Fe, NM 87503

4 Lynn Frank, Director

Oregon Department of Energy

111 Labor \& Industries Building

Salem, OR 97310
No. of

Copies

4 Dana K. Mount

P. E., Director

Division of Environmental Engr.

North Dakota State Department

of Health

1200 Missouri Avenue

Room 304

Bismark, ND 58505

4 Robert Funderberg

Department of Health \& Welfare

Statehouse

Boise, ID 83707

4 Harold Tso, Executive Director

Environmental Protection

Commission

Navajo Tribe

Window Rock, AZ 86515

4 John W. Mckiernan

Organization 4542

Sandia National Laboratory

P. 0 . Box 5800

Albuquerque, NM 87185

Gergely Markos, Manager

Uranium Research Program

South Dakota School of Mines

and Technology

Rapid City, SD 57701

Vern C. Rogers

P. E., President

Rogers \& Associates Engineering

445 East 200 South

Suite 303

Salt Lake City, UT 84111

4 Larry Anderson, Director

Bureau of Radiation \& Occupational Health

P. 0. Box 2500

Salt Lake City, UT 84110 
No. of

Copies

4 Walt Ackerman, Director

Department of Environmenta]

Quality

Land Quality Division

Hathaway Building

Cheyenne, WY 82002

Lynn Fitzrondolph

Arizona Atomic Energy Commission 2929 West Indian School Road

Phoenix, AZ 85017

Robert Overmyer

Ford, Bacon \& Davis-Utah

P. 0. Box 8009

Salt Lake City, UT 84108

W. Chappe 11

University of Colorado-Denver

P. 0. Box 136

Denver, CO 80202

D. Dressen

Los Alamos Scientific Laboratory

P. 0 . Box 1653

Los Alamos, NM 87545

W. Kislieski

Argonne National Laboratory

9700 South Cass Avenue

Argonne, IL 60439

John D. Nelson

Colorado State University

Ft. Collins, CO 80523

R. Kennedy

Ford, Bacon \& Davis-Utah

Utah Operations

2009 N. 14th Street

Suite 603

Arlington, VA 20009

F. Haywood

Oak Ridge National Laboratory

P. 0. Box $X$

Oak Ridge, TN 37830
No. of

Copies

A. Ryon

Oak Ridge National Laboratory

P. 0. Box $X$

Dak Ridge, TN 37830

W. Staub

Oak Ridge National Laboratory

P. 0. Box $X$

Dak Ridge, iN 37830

T. Tamura

Oak Ridge National Laboratory

P. 0. Box X

Oak Ridge, TN 37830

J. Morse

Colorado Energy Research

Institute

2221 East Street

Golden, C0 80401

R. 01son

Civil Engineering Department

University of Texas

Crockrell $\mathrm{Hall}$

Austin, TX 78712

Al Askew

Politech Corporation

2220 Austin National Bank Tower

Austin, TX 78701

3. N. Dybalski

Armak Company

8401 W. 47 th Street

McCook, IL 60525

\section{ONSITE}

2 DOE Richland Operations office

H. E. Ransom

3. D. White

4 Rockwe 11 Hanford Operations

J. H. Roecker

D. D. Wodrich (3) 
No. of

Copies

UNC United Nuclear Industries

F. H. Bouse

Westinghouse Hanford Company

A. G. Blasewitz

46 Pacific Northwest Laboratory

S. M. Barnes

P. A. Beedlow

W. F. Bonner

J. L. Buelt (10)

L. L. Cadwe 11

T. D. Chikalla

J. F. Cline

M. R. Elmore

D. J. Esterl

H. D. Freeman

G. W. Gee

V. Q. Hale

J. N. Hartley

P. L. Koehmstedt

J. M. Latkovich

G. B. Long (3)

J. L. McEiroy

M. C. McShane

D. A. Nelson

R. W. Nelson

B. Opitz

A. M. Platt

D. Sherwood

D. J. Silviera

P. C. Walkup/R. E. Nightingale

R. A. Walter $/ D$. B. Cearlock

M. L. Warner/B. E. Vaughan

J. Zellmer

Technical Information (5)

Publishing Coordination EI (2) 
